This item was submitted to Loughborough's Research Repository by the author.

Items in Figshare are protected by copyright, with all rights reserved, unless otherwise indicated.

\title{
Model-based comparison of hybrid propulsion systems for railway diesel multiple units
}

\section{PLEASE CITE THE PUBLISHED VERSION}

https://doi.org/10.1080/23248378.2017.1390790

\section{PUBLISHER}

(C) Taylor \& Francis

\section{VERSION}

AM (Accepted Manuscript)

\section{PUBLISHER STATEMENT}

This work is made available according to the conditions of the Creative Commons Attribution-NonCommercialNoDerivatives 4.0 International (CC BY-NC-ND 4.0) licence. Full details of this licence are available at: https://creativecommons.org/licenses/by-nc-nd/4.0/

\section{LICENCE}

CC BY-NC-ND 4.0

\section{REPOSITORY RECORD}

Schmid, Sebastian, Kambiz Ebrahimi, Antonios Pezouvanis, and Walter Commerell. 2017. "Model-based Comparison of Hybrid Propulsion Systems for Railway Diesel Multiple Units". Loughborough University. https://hdl.handle.net/2134/33368. 
1 Model-based comparison of hybrid propulsion systems for railway

2 diesel multiple units

3 Sebastian Schmid ${ }^{\mathrm{a}}$, Kambiz Ebrahimi ${ }^{\mathrm{b}}$, Antonios Pezouvanis ${ }^{\mathrm{b}}$ and Walter Commerell ${ }^{\mathrm{c}}$ 4 ${ }^{a}$ Voith Turbo GmbH \& Co. KG, Heidenheim, Germany

${ }^{b}$ Department of Aeronautical and Automotive Engineering, Loughborough University, Leicestershire, UK

8 Sebastian Schmid

9 Voith Turbo GmbH \& Co. KG, Alexanderstraße 2, 89522 Heidenheim

10 Sebastian.Schmid@ voith.com 
In order to reduce operating costs, railway vehicle operators need to find technical solutions to improve the efficiency of railway diesel multiple units on non-electrified railway routes. This can be achieved by hybridization of diesel multiple unit propulsion systems with electrical energy storage systems to enable brake energy recuperation. After highlighting the state of the art of hybrid railway vehicles and electrical energy storage systems, a simulation model of a generic diesel multiple unit in a 3-car formation is developed and equipped with three types of hybrid power transmissions. Simulations on realistic service profiles with different driving strategies show the potential for fuel consumption reduction for the different transmission types. On a suburban service profile a 3car diesel multiple unit is able to achieve simulated fuel savings of up to $24.1 \%$ and up to $18.9 \%$ on a regional service profile. 


\section{Introduction}

29 The share of electrified versus non-electrified railway lines remained fairly constant in

30 the years 2000 to 2010 [1], which shows that diesel-driven railway vehicles will continue to play an important role for passenger transport and constantly need to be improved in terms of fuel efficiency to reduce their emissions.

One of the reasons why railway vehicles receive increasing attention in terms of

34 hybridization is due to the fact that their driving behaviour can be forecasted because of

35 fixed routes with predetermined station stops and timetables. This allows for a precise prediction of fuel consumption with the help of simulation software [2-4].

Another aspect of railway vehicle hybridization comes from recovery of brake energy which in standard diesel-driven railway vehicles is dissipated as heat by hydrodynamic retarders, mechanical brakes or electric resistors. Different energy

40 storage technologies have emerged in the past for brake energy recovery purposes in the transport sector [5], but literature shows that three technologies are especially suited for on-board energy storage in railway vehicles: double-layer capacitor, flywheel and li-ion battery on-board energy storage systems [6-10].

Based on these three on-board electrical energy storage technologies, several examples of hybrid diesel multiple units (DMUs) being tested or already in service have been developed in the past years [11-19]. The high potential of railway vehicle hybridization especially for non-electrified railway systems are highlighted in a number of research projects [20-26].

Two different types of DMU propulsion systems, namely diesel-hydromechanic and diesel-electric are considered here, which are common types of railway vehicles used for passenger transportation. 

art of hybrid propulsion systems for DMUs, a literature review on electrical energy storage technologies suitable for an usage in railway vehicles is conducted. Based on a realistic use case of a DMU in a 3-car formation, the potentials in terms of fuel reduction are analysed for different combinations of power transmissions and electrical energy storage systems. The corresponding simulation results are discussed and the paper concludes with a recommendation for further research in terms of use of electrical energy storage systems for railway vehicles.

2. Hybrid diesel multiple units with electrical energy storage systems: state of the art

The following sub-sections highlight the most important hybrid railway vehicle prototypes and research projects for different types of DMU propulsion systems, namely diesel-hydromechanic (DHM) and diesel-electric (DE). The literature review focuses on railway vehicles used for passenger transportation. Freight and shunter locomotives are not considered since they represent a different use case. Light railway vehicles (e.g. trams) running under catenaries that do not make use of an on-vehicle diesel engine as prime mover are per definition not hybrid vehicles [27] and will not be

69 considered in this work.

\subsection{Hybrid diesel-hydromechanic railway vehicles}

71 In the automotive industry a growing number of vehicles already make usage of a

72 hybrid hydromechanic transmission, such as the ZF hybrid 8HP transmission [28]. In

73 the rail sector a similar approach has so far only been addressed by MTU. In 2008 MTU

74 presented the concept of a parallel hybrid powerpack for railway vehicles. It consists of

75 a $275 \mathrm{~kW}$ diesel engine, a crankshaft starter generator (CSG) and a ZF Ecomat 5-speed 
automatic hydromechanic gearbox. During braking the CSG converts kinetic energy of

77 the railway vehicle into electrical power and temporarily stores it in a lithium-ion battery module. According to simulation results the fuel consumption for a typical regional speed profile can be reduced by $16 \%$ with this system [14]. During trial runs a

80 Class 642 equipped with two hybrid MTU powerpacks was able to achieve a 15\%

81 reduction in fuel consumption [15].

\subsection{Hybrid diesel-electric railway vehicles}

In 2003 the East Japan Railway Company (JR East) developed a test platform for different innovative propulsion systems in collaboration with Hitachi Ltd. The vehicle called New Energy (NE) train has been equipped with a series hybrid system based on a diesel engine as prime mover in combination with a lithium ion battery as energy storage. Several alternatives have been considered when choosing the most suitable type of energy storage technology (double-layer capacitors, lead acid battery, NiMH battery or Li-Ion battery). The decision was made in favour of a Li-Ion battery with an energy content of $10 \mathrm{kWh}$ since it offers the best compromise of energy and power density [16].

Based on the results achieved with the NE train, JR East and Hitachi Ltd.

decided to build three further series hybrid diesel-electric multiple-units (DEMU) called

94 Kiha E200 Hybrid. The vehicle has a diesel-electric propulsion system with a Li-Ion battery connected to the DC link as secondary energy source. In addition to the battery an auxiliary power supply module is connected to the DC link. This allows for an emission free operation during standstill of the vehicle with shut off diesel engine. The

98 following results were achieved when comparing the Kiha E200 series hybrid vehicle to 99 a non-hybrid DEMU on the same route [17]. 
- Fuel saving of $10 \%$ on the Koumi-line

- $60 \%$ less exhaust emission by using a Common Rail diesel engine

- $30 \mathrm{~dB}$ noise reduction by using a pure electric mode up to a speed of $25 \mathrm{~km} / \mathrm{h}$

In 2007, Hitachis' hybrid propulsion system using lithium-ion batteries was installed in a British Class 43 railcar to allow realistic trials of the prototype technology. The trials demonstrated fuel savings on the single railcar ranging from $12 \%$ on long runs up to $20 \%$ on duties with frequent braking [18].

An Alstom Coradia LIREX ${ }^{\circledR}$ test carrier DEMU was equipped with a flywheel energy recuperation system in the year 2001 [19]. The carbon fibre and epoxy resin flywheel had a diameter of $700 \mathrm{~mm}$ and a maximum speed of $25.000 \mathrm{rpm}$. The DEMU test carrier was equipped with two flywheel systems but literature is not providing any measured figures about the achieved improvements in fuel efficiency with the flywheel energy storage system. Simulation results have shown that the energy consumption on a $90 \mathrm{~km}$ long track in Germany would reduce from $295 \mathrm{kWh}$ to $264 \mathrm{kWh}$ [20]. That's a simulated energy reduction of $10.5 \%$.

\subsection{European railway vehicle hybridization projects}

In 2002, one of the first EU projects dealing with hybrid propulsion systems for railway vehicles was ULEV-TAP 2 co-funded by the European Commission, which focused on series electric hybrid concepts for light rail applications [21]. The main objective of the project was to research and develop the central hardware required for a series electric hybrid drive based on a flywheel technology energy storage system. The result of the simulations showed that the developed control strategy and the development of the hybrid power train concept are highly efficient. The fuel consumption was significantly reduced by $42 \%$ in the particular case of Karlsruhe, Germany. 
A further EU project which was settled in the area of railway vehicle optimization was CleanER-D. Sub-project 7 of CleanER-D was dealing with the simulation of hybrid systems for railway vehicles. Different generic vehicles and duty cycles were defined in order to compare energy storage technologies against each other. Five different energy storage technologies were considered in the study: double-layer capacitor, hydrostatic accumulator, flywheel, lithium-ion battery and a combination of

130 lithium-ion battery and double-layer capacitor. The simulated hybrid vehicles achieved

131 fuel reductions in the range of $10.9 \%$ up to $26.6 \%$ depending on system architecture, 132 energy storage system and duty cycle [24]. the benefits of a hybrid high-speed train (HST) on UK routes and gave future design considerations based on simulation results. The study was divided into two phases. In phase one a British Rail Class 220 DEMU was modelled in MATLAB/Simulink@. Two high-speed routes in England have been simulated with the vehicle model. One of them was on the Great Western Railway (GWR) from London Paddington to Bristol Temple

139 Meads and the second route was based on the East Coast Mainline (ECML) and went

140 from Newcastle to London Kings Cross. The simulated fuel consumption on the two 141 routes was 1.32 litres per 100 seat $\mathrm{kms}$ on the GWR route and 1.14 litres per 100 seat $142 \mathrm{kms}$ on the ECML route [25]. In phase two of the study, the diesel-electric propulsion

143 system was equipped with a nickel metal hydride (NiMH) chemistry battery pack

144 having an energy content of $500 \mathrm{kWh}$ [25]. With the final battery state of charge (SOC)

145 being the same as the initial SOC, an improvement in cumulative fuel consumption of $14616 \%$ for the GWR drive cycle was achieved. The reduction for the ECML route was in

147 the order of $8 \%$. The scope of the DfT study was extended in a second step and the 148 existing model was adapted to simulate a two coach Class 150 and a two coach Class 
149144 DMU [26] operating on routes around the Welsh Valleys and the Birmingham

150 Area. Similar to the preceding study a NiMH battery pack was chosen and simulation

151 results for both routes showed overall fuel consumption improvements of up to $25 \%$.

\subsection{Overview of fuel saving potentials}

153 As described in the preceding sections, vehicle prototypes of different rail companies,

154 as well as European and governmental projects have been dealing with railway vehicle

155 hybridization. Most of the results promise double-digit improvements in terms of fuel

156 consumption. Table 5 shows a compilation of the analysed literature and the stated

157 figures on fuel savings. Only electric energy storage systems are regarded in the table,

158 since these types of technologies will be discussed and evaluated in the present paper.

159 Table 1. Overview of potential fuel savings of hybrid diesel multiple units as described 160 in [14-21, 24-26].

\begin{tabular}{|c|c|c|c|c|c|}
\hline Vehicle & $\begin{array}{l}\text { Propulsion } \\
\text { System }\end{array}$ & ESS & $\begin{array}{l}\text { Fuel } \\
\text { Savings }\end{array}$ & $\begin{array}{l}\text { Type of } \\
\text { Research }\end{array}$ & Reference \\
\hline $\begin{array}{l}\text { Siemens Desiro Classic } \\
\text { Hybrid }\end{array}$ & DHM & Li-Ion battery & $16 \%$ & $\begin{array}{l}\text { Simulation } \\
\text { study }\end{array}$ & {$[14]$} \\
\hline $\begin{array}{l}\text { Siemens Desiro Classic } \\
\text { Hybrid }\end{array}$ & DHM & Li-Ion battery & $15 \%$ & Field test & [15] \\
\hline Hitachi New Energy Train & $\mathrm{DE}$ & Li-Ion battery & $\mathrm{n} / \mathrm{a}$ & Prototype & [16] \\
\hline Hitachi Kiha E200 & $\mathrm{DE}$ & Li-Ion battery & $10 \%$ & Field test & [17] \\
\hline British Class 43 & $\mathrm{DE}$ & Li-Ion battery & $\begin{array}{l}12-20 \\
\%\end{array}$ & Field test & [18] \\
\hline Alstom Coradia LIREX ${ }^{\circledR}$ & $\mathrm{DE}$ & Flywheel & $10.5 \%$ & $\begin{array}{l}\text { Simulation } \\
\text { study }\end{array}$ & {$[19,20]$} \\
\hline Siemens Avanto Hybrid & $\mathrm{DE}$ & Flywheel & $48 \%$ & $\begin{array}{l}\text { Simulation } \\
\text { study }\end{array}$ & {$[21]$} \\
\hline $\begin{array}{l}\text { CleanER-D suburban } \\
\text { vehicle }\end{array}$ & DHM & Flywheel & $12 \%$ & $\begin{array}{l}\text { Simulation } \\
\text { study }\end{array}$ & {$[24]$} \\
\hline $\begin{array}{l}\text { CleanER-D suburban } \\
\text { vehicle }\end{array}$ & $\mathrm{DE}$ & $\begin{array}{l}\text { Double-Layer } \\
\text { Capacitor }\end{array}$ & $10.4 \%$ & $\begin{array}{l}\text { Simulation } \\
\text { study }\end{array}$ & {$[24]$} \\
\hline $\begin{array}{l}\text { CleanER-D regional } \\
\text { vehicle ( } 360 \mathrm{~kW} \text { diesel } \\
\text { engine) }\end{array}$ & DHM & Li-Ion battery & $16.5 \%$ & $\begin{array}{l}\text { Simulation } \\
\text { study }\end{array}$ & [24] \\
\hline
\end{tabular}




\begin{tabular}{|c|c|c|c|c|}
\hline $\begin{array}{l}\text { CleanER-D regional } \\
\text { vehicle ( } 360 \mathrm{~kW} \text { diesel } \\
\text { engine) }\end{array}$ & $\mathrm{DE}$ & Li-Ion battery & $24.2 \%$ & $\begin{array}{l}\text { Simulation [24] } \\
\text { study }\end{array}$ \\
\hline $\begin{array}{l}\text { CleanER-D regional } \\
\text { vehicle ( } 560 \mathrm{~kW} \text { diesel } \\
\text { engine) }\end{array}$ & $\mathrm{DE}$ & Flywheel & $18.7 \%$ & $\begin{array}{l}\text { Simulation [24] } \\
\text { study }\end{array}$ \\
\hline $\begin{array}{l}\text { CleanER-D regional } \\
\text { vehicle ( } 560 \mathrm{~kW} \text { diesel } \\
\text { engine) }\end{array}$ & $\mathrm{DE}$ & $\begin{array}{l}\text { Double-Layer } \\
\text { Capacitor }\end{array}$ & $16.2 \%$ & $\begin{array}{l}\text { Simulation [24] } \\
\text { study }\end{array}$ \\
\hline $\begin{array}{l}\text { CleanER-D regional } \\
\text { vehicle }(560 \mathrm{~kW} \text { diesel } \\
\text { engine) }\end{array}$ & $\mathrm{DE}$ & $\begin{array}{l}\text { Double-Layer } \\
\text { Capacitor } / \mathrm{Li}- \\
\text { Ion battery }\end{array}$ & $26.6 \%$ & $\begin{array}{l}\text { Simulation [24] } \\
\text { study }\end{array}$ \\
\hline Class 220 Hybrid & $\mathrm{DE}$ & NiMH Battery & $8-16 \%$ & $\begin{array}{l}\text { Simulation [25] } \\
\text { study }\end{array}$ \\
\hline Class 150 Hybrid & $\mathrm{DE}$ & NiMH Battery & $18-26 \%$ & $\begin{array}{l}\text { Simulation [26] } \\
\text { study }\end{array}$ \\
\hline Class 144 Hybrid & $\mathrm{DE}$ & NiMH Battery & $17-26 \%$ & $\begin{array}{l}\text { Simulation [26] } \\
\text { study }\end{array}$ \\
\hline
\end{tabular}

\section{$161 \quad 2.5 . \quad$ Literature review on electrical energy storage technologies}

\section{2.5.1. Double-layer capacitors}

163 Double-layer capacitors (DLCs) are gaining importance in terms of using them as

164 energy storage in hybrid railway vehicles as highlighted in [11-13]. Because of their

165 low internal resistance, higher power densities can be realized compared to Li-Ion

166 batteries. For this reason, as well as their cyclic lifetime of up to 1 million cycles as

167 shown in [29], they are used for short-time storage of brake energy in railway vehicles.

168 One example of an existing solution is the Sitras ${ }^{\circledR}$ mobile energy storage system by

169 Siemens [30]. One manufacturer of DLCs for "Heavy Duty" applications (e.g. buses

170 and train vehicles) is Maxwell Technologies. A specially designed DLC module

171 BMOD0063 with an usable energy content of $137 \mathrm{Wh}$ is commercially available [29].

172 This DLC module will be used for the regarded hybrid DMU since it is commercially

173 available and has already been used for hybrid heavy duty applications [31]. 
175 In a flywheel energy is stored by accelerating a rotor to a high rotational speed of up to

$17636,000 \mathrm{rpm}$ [32]. By decelerating the rotor with the help of an electric generator, the

177 rotational kinetic energy can be transformed to electric energy. In order to increase the

178 efficiency of flywheel energy storage systems, current developments try to reduce

179 friction losses as far as possible by evacuating the chamber in which the rotor is

180 spinning. Another means is using almost frictionless magnetic bearings which require a 181 sophisticated control system.

182 In 2011 a US Department of Energy study assessed high power flywheel energy storage systems for hybrid vehicles [33]. Different concepts of flywheel ESS where evaluated in terms of important factors for an use in light and heavy duty hybrid vehicles. The study divided the examined flywheel ESS in systems which are especially suited for light duty applications (e.g. cars) and systems for heavy duty applications (e.g. trucks, trams and trains). For heavy duty applications such as a hybrid DMU, a minimum delivered energy of $2 \mathrm{kWh}$ and a power output above $150 \mathrm{~kW}$ was suggested. The two potential suppliers who fell into this category are the centre for concepts in mechatronics (CCM) and the L-3 Communications Magnet-Motor GmbH (L-3 MM). The CCM offers flywheel ESS in four different configurations [34], two of which (RxV-I and RxV-II)

192 are of interest for railway vehicles in terms of power output and storable energy. Table 6 shows a comparison of the CCM RxV-I, CCM RxV-II and the flywheel offered by L3 MM. Empty cells indicate that no values are given in literature. The RxV-II with a maximum power output of $300 \mathrm{~kW}$ and an energy content of

$1964 \mathrm{kWh}$ has already been used in a LRV project [21]. The weight of the flywheel ESS

197 including power electronics and cooling system was $1100 \mathrm{~kg}$, which results in an overall system energy density of $3.6 \mathrm{Wh} / \mathrm{kg}$ and power density of $272 \mathrm{~W} / \mathrm{kg}$, which is in 
199 good accordance with the values achieved with the Alstom Coradia LIREX $^{\circledR}$ test carrier

200 DEMU (5 Wh/kg and $269 \mathrm{~W} / \mathrm{kg})$ [19].

201 Table 2. Technical data of CCM and L-3 MM flywheel ESS [33, 34].

\begin{tabular}{|c|c|c|c|}
\hline & $\begin{array}{c}\text { CCM Flywheel } \\
\text { RxV-I }\end{array}$ & $\begin{array}{c}\text { CCM Flywheel } \\
\text { RxV-II }\end{array}$ & L-3 MM Flywheel \\
\hline Energy Content & $2 \mathrm{kWh}$ & $4 \mathrm{kWh}$ & $2 \mathrm{kWh}$ \\
\hline $\begin{array}{l}\text { Type of } \\
\text { Motor/Generator }\end{array}$ & $\begin{array}{l}\text { Synchronous } \\
\text { machine, } \\
\text { permanent } \\
\text { excitation }\end{array}$ & $\begin{array}{l}\text { Synchronous } \\
\text { machine, permanent } \\
\text { excitation }\end{array}$ & $\begin{array}{l}\text { Synchronous } \\
\text { machine, } \\
\text { permanent } \\
\text { excitation }\end{array}$ \\
\hline Maximum Power & $\begin{array}{l}150 \mathrm{~kW}(50 \mathrm{sec} \\
\max )\end{array}$ & $\begin{array}{l}300 \mathrm{~kW}(50 \mathrm{sec} \\
\max )\end{array}$ & $300 \mathrm{~kW}$ \\
\hline Continuous Power & $\begin{array}{l}\text { no information } \\
\text { available }\end{array}$ & $200 \mathrm{~kW}$ & $100 \mathrm{~kW}$ \\
\hline $\begin{array}{l}\text { Round-trip } \\
\text { efficiency }\end{array}$ & $\begin{array}{l}\text { no information } \\
\text { available }\end{array}$ & $90 \%$ & $87 \%$ \\
\hline Voltage & $\begin{array}{l}\text { no information } \\
\text { available }\end{array}$ & $420-800 \mathrm{VDC}$ & Up to $750 \mathrm{VDC}$ \\
\hline $\begin{array}{l}\text { Flywheel ESS } \\
\text { Mass }\end{array}$ & $225 \mathrm{~kg}$ & $375 \mathrm{~kg}$ & $400 \mathrm{~kg}$ \\
\hline Specific Energy & $8.9 \mathrm{Wh} / \mathrm{kg}$ & $10.6 \mathrm{Wh} / \mathrm{kg}$ & $5 \mathrm{Wh} / \mathrm{kg}$ \\
\hline Specific Power & $666 \mathrm{~W} / \mathrm{kg}$ & $800 \mathrm{~W} / \mathrm{kg}$ & $750 \mathrm{~W} / \mathrm{kg}$ \\
\hline
\end{tabular}

\subsubsection{Lithium-Ion batteries}

203 Due to the achievable power and energy densities, Lithium-Ion (Li-Ion) batteries are

204 regarded as the key technology for current and upcoming hybrid and electric vehicles.

205 Various manufacturers offer Li-Ion batteries based on different cell chemistries, either

206 suited for high power or high energy applications. A high power output is ideal for

207 applications where electric traction is required in heavy duty transportation (e.g. hybrid

208 railway vehicles), while a high energy density ensures enough range for battery electric

209 vehicles.

210 For the simulative analysis of hybrid DMUs as described in this paper, SCiB ${ }^{\mathrm{TM}}$

211 li-ion cells of Japanese manufacturer Toshiba based on lithium nickel manganese cobalt

212 oxide (NMC) chemistry with a lithium titanium oxide (LTO) anode and 20 Ah nominal 
213 capacity will be used. They offer a good compromise between energy density, power

214 density and achievable lifetime according to [35, 36].

\section{2.6. Definition of hybrid DMU case studies for simulative analyses}

216 In order to simulate potential fuel savings by hybridizing DMUs with electrical ESS, a

217 generic 3-car DMU is defined in this paper. The vehicle is equipped with two or three

218 railpacks (cf. Figure 1) depending on the installed diesel engine power.

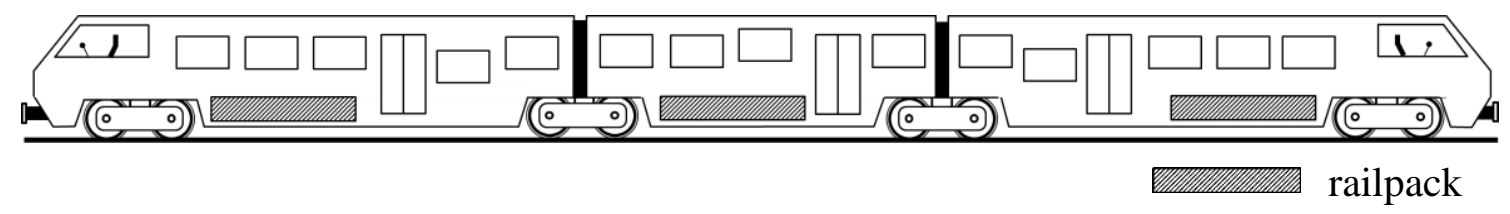

220 Figure 1. Schematic drawing of three-car diesel multiple unit.

221 Table 3 summarizes the main vehicle parameters used for the simulation studies

222 described in this paper. The parameters correspond with DMUs commonly used for

223 passenger transportation on non-electrified railway routes and the overall weight of the

224 vehicle includes an average load factor with all seats occupied by passengers.

225 Table 3. Vehicle parameters of standard DMU-3 without hybrid system components.

\begin{tabular}{clll}
\hline Parameter & Unit & Value & Description \\
\hline$m_{\text {train }}$ & $(\mathrm{t})$ & 125.0 & Overall mass of rail vehicle \\
$\eta_{\text {mech }}$ & $(\%)$ & 97 & Efficiency of final drive \\
$\mathrm{D}_{w}$ & $(\mathrm{~m})$ & 0.85 & Wheel diameter \\
$v_{\text {Max }}$ & $(\mathrm{km} / \mathrm{h})$ & 160 & Top speed of vehicle \\
$a_{\text {max }}$ & $\left(\mathrm{m} / \mathrm{s}^{2}\right)$ & 1.2 & Maximum permitted acceleration \\
$a_{\min }$ & $\left(\mathrm{m} / \mathrm{s}^{2}\right)$ & 0.6 & Average deceleration during braking phases \\
$A$ & $\left(\mathrm{~m}^{2}\right)$ & 10.3 & Vehicle frontal area \\
$c_{w}$ & $(-)$ & 0.8 & Vehicle drag coefficient \\
$m_{a d h}$ & $(\mathrm{t})$ & 57.0 & Adhesion mass \\
$f_{a d h}$ & $(-)$ & 0.25 & Adhesion factor wheel/rail contact \\
\hline
\end{tabular}




\subsection{Standard and hybrid powertrain configurations}

227 Three different types of power transmissions to transfer power to the wheels are

228 simulated in the present paper. Two of them are hydromechanic and one is diesel-

229 electric. In Table 4 the main parameters used for the simulation of the power

230 transmissions are summarized.

231 Table 4. Parameters and weight of power transmission and hybrid components.

\begin{tabular}{|c|c|c|c|}
\hline Vehicle & 3-car DMU & 3-car DMU & 3-car DMU \\
\hline Power transmission & $\begin{array}{l}\text { Diesel- } \\
\text { hydromechanic } \\
\text { (4-speed } \\
\text { transmission) }\end{array}$ & $\begin{array}{l}\text { Diesel- } \\
\text { hydromechanic } \\
\text { (6-speed automatic } \\
\text { gearbox) }\end{array}$ & Diesel-electric \\
\hline $\begin{array}{l}\text { Diesel engine power } \\
\text { output }\end{array}$ & $390 \mathrm{~kW}$ & $588 \mathrm{~kW}$ & $588 \mathrm{~kW}$ \\
\hline Number of railpacks & 3 & 2 & 2 \\
\hline $\begin{array}{l}\text { Maximum permissible } \\
\text { power input to } \\
\text { transmission }\end{array}$ & up to $320 \mathrm{~kW}$ & up to $588 \mathrm{~kW}$ & $\begin{array}{l}588 \mathrm{~kW} \\
\text { (mechanical input } \\
\text { power to generator) }\end{array}$ \\
\hline $\begin{array}{l}\text { Maximum permissible } \\
\text { torque input to } \\
\text { transmission }\end{array}$ & up to $1,900 \mathrm{Nm}$ & up to $3,350 \mathrm{Nm}$ & $\begin{array}{l}3,350 \mathrm{Nm} \\
\text { (mechanical input } \\
\text { torque to generator) }\end{array}$ \\
\hline $\begin{array}{l}\text { Mean mechanical } \\
\text { auxiliaries power demand } \\
\text { during traction }\end{array}$ & $11 \mathrm{~kW}$ & $16 \mathrm{~kW}$ & $16 \mathrm{~kW}$ \\
\hline $\begin{array}{l}\text { Mean mechanical } \\
\text { auxiliaries power demand } \\
\text { during idling }\end{array}$ & $3 \mathrm{~kW}$ & $5 \mathrm{~kW}$ & $5 \mathrm{~kW}$ \\
\hline $\begin{array}{l}\text { Mean mechanical } \\
\text { auxiliaries power demand } \\
\text { during braking }\end{array}$ & $15 \mathrm{~kW}$ & $30 \mathrm{~kW}$ & $15 \mathrm{~kW}$ \\
\hline $\begin{array}{l}\text { Mean mechanical } \\
\text { auxiliaries power demand } \\
\text { during coasting }\end{array}$ & $3 \mathrm{~kW}$ & $5 \mathrm{~kW}$ & $5 \mathrm{~kW}$ \\
\hline Type of E-Motor & AC induction motor & $\begin{array}{l}\text { Synchronous } \\
\text { machine, permanent } \\
\text { excitation }\end{array}$ & $\begin{array}{l}\text { Two AC induction } \\
\text { motors per railpack }\end{array}$ \\
\hline $\begin{array}{l}\text { E-Motor peak power } \\
\text { output }\end{array}$ & $230 \mathrm{~kW}$ & $230 \mathrm{~kW}$ & $2 \times 250 \mathrm{~kW}$ \\
\hline E-Motor maximum speed & $2,640 \mathrm{rpm}$ & $2,000 \mathrm{rpm}$ & $6,000 \mathrm{rpm}$ \\
\hline
\end{tabular}




\begin{tabular}{|c|c|c|c|}
\hline $\begin{array}{l}\text { E-Motor maximum } \\
\text { continuous torque output }\end{array}$ & 2,915 Nm [42] & $1,100 \mathrm{Nm}[42]$ & $2 \times 5,000 \mathrm{Nm}$ \\
\hline E-Motor mean efficiency & $85 \%$ & $90 \%$ & $85 \%$ \\
\hline
\end{tabular}

As described by Paukert in [23] a maximum permissible weight for the hybrid

234 components per railpack is defined. The authors of this paper have chosen an additional

235 weight of $1000 \mathrm{~kg}$ per railpack for the sum of the following hybrid components: E-

236 motor, energy storage cooling system (ESC), propulsion control system (PCS) and

237 energy storage system (ESS). This results in a permissible weight for the ESS as

238 highlighted in Table 5.

239 Table 5. Weight of hybrid components and restrictions for energy storage system.

\begin{tabular}{|c|c|c|c|c|}
\hline Description & Unit & $\begin{array}{l}\text { Hybrid 3-coach DMU } \\
\text { with DHM 4-speed } \\
\text { transmission }\end{array}$ & $\begin{array}{l}\text { Hybrid 3-coach DMU } \\
\text { with DHM 6-speed } \\
\text { transmission }\end{array}$ & $\begin{array}{l}\text { Hybrid 3-coach DMU } \\
\text { with diesel-electric } \\
\text { propulsion system }\end{array}$ \\
\hline E-Motor (EM) & $(\mathrm{kg})$ & $400[42]$ & 150 [42] & - \\
\hline $\begin{array}{l}\text { Energy storage } \\
\text { cooling system } \\
\text { (ESC) }\end{array}$ & $(\mathrm{kg})$ & $150[44]$ & $150[44]$ & $150[44]$ \\
\hline $\begin{array}{l}\text { Propulsion } \\
\text { control system } \\
\text { (PCS) }\end{array}$ & $(\mathrm{kg})$ & $100[44]$ & 100 [44] & $100[44]$ \\
\hline Sum & $(\mathrm{kg})$ & 650 & 400 & 250 \\
\hline $\begin{array}{l}\text { Restriction for } \\
\text { hybrid } \\
\text { components }\end{array}$ & $(\mathrm{kg})$ & 1000 [23] & 1000 [23] & 1000 [23] \\
\hline $\begin{array}{l}\text { Permissible } \\
\text { weight for } \\
\text { energy storage } \\
\text { system (ESS) }\end{array}$ & $(\mathrm{kg})$ & 350 & 600 & 750 \\
\hline
\end{tabular}

240

\section{$241 \quad 2.8 . \quad$ Track characteristics}

242 Two generic track profiles namely 'suburban service' and 'regional service' are used for

243 the studies as defined in [43]. The first one is based on a suburban service profile with

244 an overall length of $40 \mathrm{~km}$ and 12 station stops and the second one on a regional service 
245 profile with an overall length of $70 \mathrm{~km}$ and 15 station stops. Both profiles are flat with 246 no gradients.

247 Table 6 shows the journey and station dwell times for the suburban and regional service 248 profiles. To simulate a realistic behaviour of a railway vehicle, first an outward journey

249 is undertaken in the simulation which is then followed by a 10 minute driver break.

250 After this break the return journey is simulated until the vehicle arrives again at the start

251 position. During the break the engine is kept idling for the studies conducted in this

252 paper, which is a common procedure for railway vehicles in order to provide energy for

253 the auxiliaries (e.g. air condition and brake system).

254 Table 6. Journey and station dwell times for the suburban and regional service profile $255[22,43]$.

\begin{tabular}{|c|c|c|c|c|c|c|c|}
\hline \multirow{2}{*}{$\overline{\text { Start }}$} & \multirow[b]{2}{*}{ Stop } & \multicolumn{2}{|c|}{ Length } & \multicolumn{2}{|c|}{ Journey time } & \multicolumn{2}{|c|}{ Station dwell time } \\
\hline & & Suburban & Regional & Suburban & Regional & Suburban & Regional \\
\hline $\begin{array}{l}\text { Station } \\
\text { A }\end{array}$ & Station B & $2 \mathrm{~km}$ & $2 \mathrm{~km}$ & $140.0 \mathrm{sec}$ & $142.0 \mathrm{sec}$ & $60 \mathrm{sec}$ & $60 \mathrm{sec}$ \\
\hline Station B & Station C & $3 \mathrm{~km}$ & $3 \mathrm{~km}$ & $154.0 \mathrm{sec}$ & $157.0 \mathrm{sec}$ & $60 \mathrm{sec}$ & $60 \mathrm{sec}$ \\
\hline Station C & Station D & $2 \mathrm{~km}$ & $5 \mathrm{~km}$ & $117.0 \mathrm{sec}$ & $221.0 \mathrm{sec}$ & $60 \mathrm{sec}$ & $60 \mathrm{sec}$ \\
\hline $\begin{array}{l}\text { Station } \\
\text { D }\end{array}$ & Station E & $3 \mathrm{~km}$ & $8 \mathrm{~km}$ & $153.0 \mathrm{sec}$ & $319.0 \mathrm{sec}$ & $60 \mathrm{sec}$ & $120 \mathrm{sec}$ \\
\hline Station E & Station F & $5 \mathrm{~km}$ & $3 \mathrm{~km}$ & $218.0 \mathrm{sec}$ & $155.0 \mathrm{sec}$ & $60 \mathrm{sec}$ & $60 \mathrm{sec}$ \\
\hline Station F & Station $\mathrm{G}$ & $6 \mathrm{~km}$ & $5 \mathrm{~km}$ & $245.0 \mathrm{sec}$ & $217.0 \mathrm{sec}$ & $60 \mathrm{sec}$ & $60 \mathrm{sec}$ \\
\hline $\begin{array}{l}\text { Station } \\
\mathrm{G}\end{array}$ & Station $\mathrm{H}$ & $5 \mathrm{~km}$ & $9 \mathrm{~km}$ & $214.0 \mathrm{sec}$ & $332.0 \mathrm{sec}$ & $60 \mathrm{sec}$ & $120 \mathrm{sec}$ \\
\hline $\begin{array}{l}\text { Station } \\
\mathrm{H}\end{array}$ & Station I & $3 \mathrm{~km}$ & $3 \mathrm{~km}$ & $153.0 \mathrm{sec}$ & $155.0 \mathrm{sec}$ & $60 \mathrm{sec}$ & $60 \mathrm{sec}$ \\
\hline Station I & Station $\mathbf{J}$ & $2 \mathrm{~km}$ & $6 \mathrm{~km}$ & $117.0 \mathrm{sec}$ & $245.0 \mathrm{sec}$ & $60 \mathrm{sec}$ & $60 \mathrm{sec}$ \\
\hline Station J & Station K & $7 \mathrm{~km}$ & $10 \mathrm{~km}$ & $319.0 \mathrm{sec}$ & $348.0 \mathrm{sec}$ & $60 \mathrm{sec}$ & $120 \mathrm{sec}$ \\
\hline $\begin{array}{l}\text { Station } \\
\mathrm{K}\end{array}$ & Station L & $2 \mathrm{~km}$ & $6 \mathrm{~km}$ & $141.0 \mathrm{sec}$ & $244.0 \mathrm{sec}$ & $600 \mathrm{sec}$ & $60 \mathrm{sec}$ \\
\hline Station L & Station M & & $4 \mathrm{~km}$ & & $187.0 \mathrm{sec}$ & & $60 \mathrm{sec}$ \\
\hline $\begin{array}{l}\text { Station } \\
\text { M }\end{array}$ & Station N & & $3 \mathrm{~km}$ & & $156.0 \mathrm{sec}$ & & $60 \mathrm{sec}$ \\
\hline $\begin{array}{l}\text { Station } \\
\mathrm{N}\end{array}$ & Station O & & $3 \mathrm{~km}$ & & $172.0 \mathrm{sec}$ & & $600 \mathrm{sec}$ \\
\hline
\end{tabular}




\subsection{D simulation models of hybrid diesel-driven railway vehicles}

\subsubsection{Simulation approach and general outline}

258 A generic outline of a hybrid propulsion system for a railway vehicle is shown in Figure

259 2. Using a forward simulation approach the output of a virtual driver is used to control

260 the railpack, consisting of the internal combustion engine (ICE), power transmission,

261 auxiliary systems and the energy storage system. An engine control is implemented to

262 ensure that the ICE and power transmission operate within their boundaries (e.g.

263 permissible rotational speed, torque and power limits). Energy management functions

264 regulate the power distribution between the energy storage system, auxiliary systems,

265 power transmission and the internal combustion engine. A driving strategy state

266 machine is implemented to control the different driving phases (e.g. acceleration and

267 braking) and to guarantee a realistic behaviour of the simulated railway vehicle.

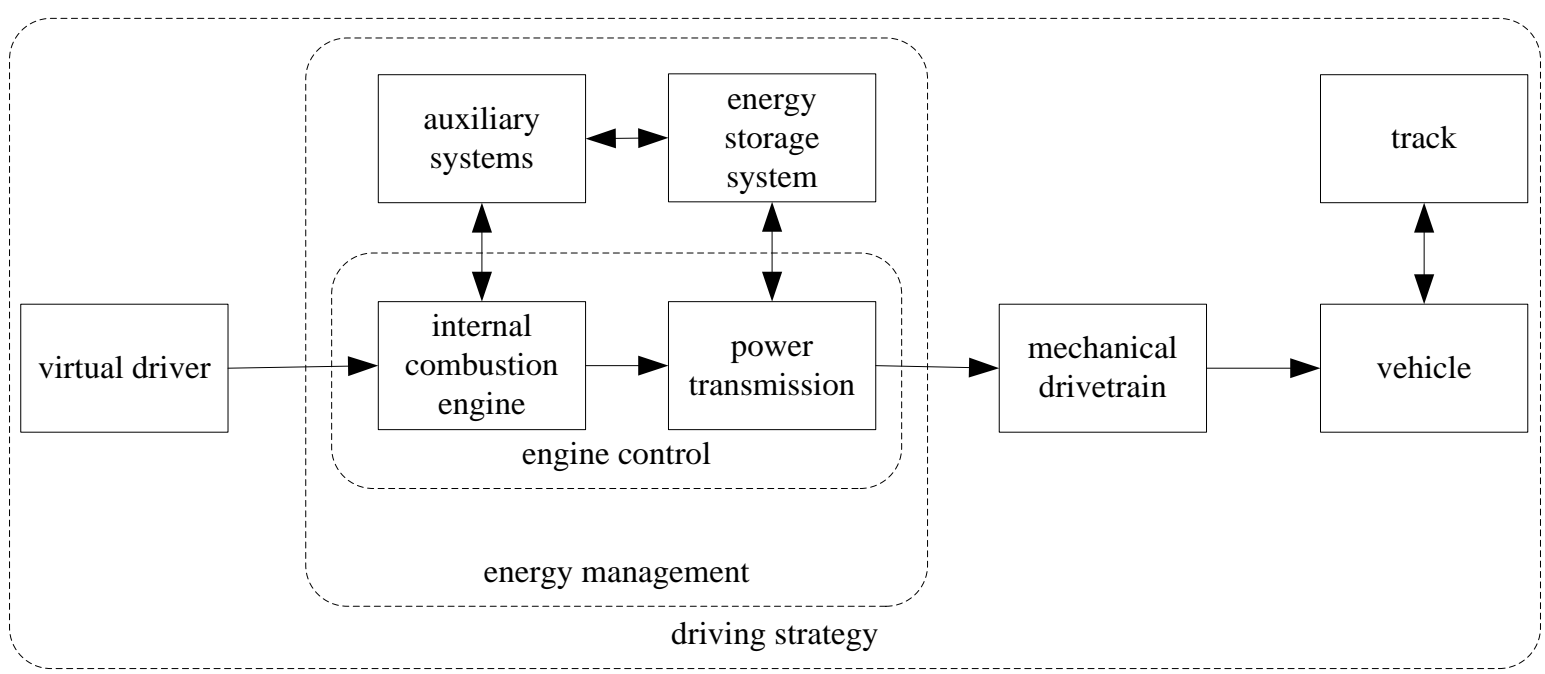

269 Figure 2. General outline of a hybrid propulsion system for a railway vehicle including

270 necessary control systems.

The function of engine control is to limit the torque and power output of the ICE according to the maximum permissible input torque and power of the used power transmission. In terms of a hydromechanic transmission, another important aspect is the 
maximum transferable tractive force via the wheel/rail contact limited by the adhesion

276 factor. Engine control also ensures that the current tractive effort stays below this limit.

277 The following energy management function is used to control the power

278 distribution between ICE and energy storage system (ESS) during different driving

279 conditions: In boost mode the ESS provides additional power to the power transmission

280 during acceleration phases. Hence, the vehicle achieves a better performance compared

281 to a standard vehicle with no ESS. During braking phases kinetic energy of the vehicle

282 is fed back to the ESS. A parameter 'boost' is introduced which defines the ratio

283 between E-motor and diesel engine power output during traction phases.

\subsubsection{Driving strategy}

285 A driving condition state machine controls the overall vehicle behaviour to ensure that

286 the vehicle doesn't violate any speed limits on the track and that all stations are reached

287 as specified by the timetable. A typical speed profile of a DMU between two station

288 stops can generally be divided into four phases: acceleration phase, speed holding

289 phase, coasting phase and braking phase as described in $[37,38]$.

- During acceleration phases all of the currently available diesel engine power is used to accelerate the railway vehicle. In case of a hybrid DMU additional power is supplied by the ESS to the power transmission. The diesel engine power is limited in terms of permissible input power or torque to the power transmission and the maximum transferable traction force via the wheel/rail contact.

- The transition from acceleration to speed holding usually occurs when the current speed limit on the track is reached. During this phase two different driving styles can be applied. The virtual driver either holds the speed constant 
at the given speed limit or a so called 'saw tooth' driving style is used, which is characterized by a regular switch from traction over to coasting phases and vice versa.

- The speed holding phase, either constant or with a saw tooth driving style, is followed by a final coasting phase before the vehicle brakes into the station stop. Coasting phases are a very effective tool used by experienced railway vehicle drivers to save traction energy and they refer to the time when no traction force is applied to the wheels. In the present paper a new approach is introduced to investigate on different

311 driving strategies and to find the most favourable for standard vehicles and for hybrid

312 vehicles in terms of fuel consumption. An automated train control was implemented in

313 the simulation models on the basis of research conducted by Milroy and Forsythe [39]

314 in order to arrive at the next station within a variation of $\pm 1 \%$ of the given journey

315 time for the current section. The user of the simulation models has the ability to choose

316 if a saw tooth driving style shall be applied and if the virtual driver shall make use of

317 coasting phases. The idea behind this variability is to investigate if a hybrid DMU

318 requires different driving strategies compared to a conventional DMU. Figure 3 shows

319 the four types of driving strategies which are feasible with the programmed automated train control for an exemplary journey. 
(a)

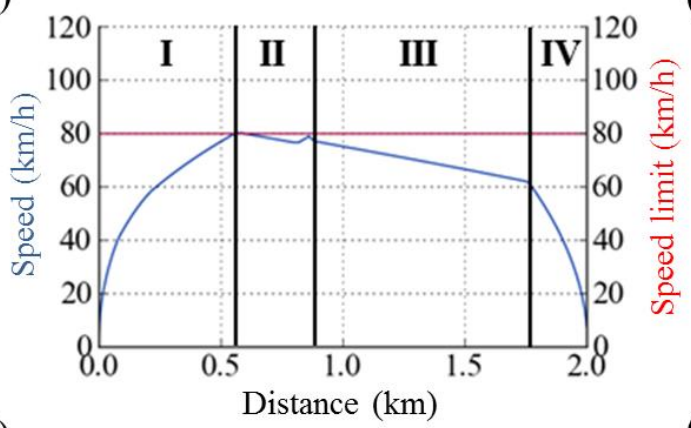

(c)

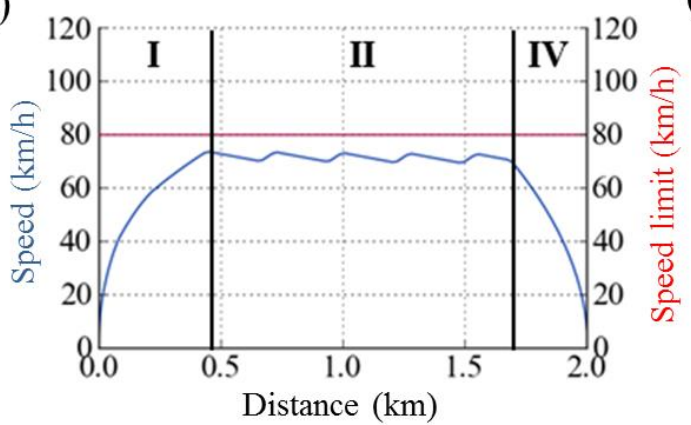

(b)

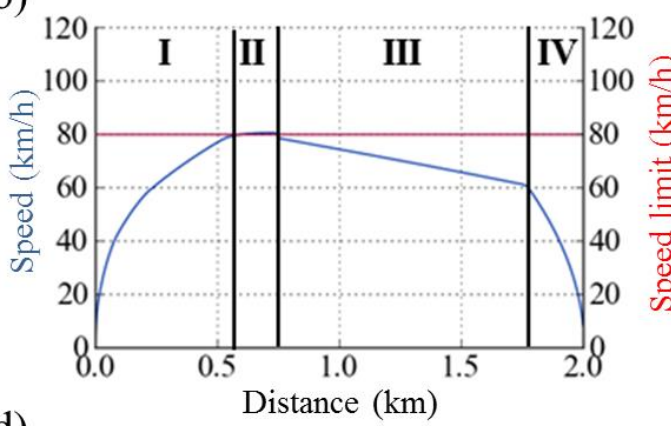

(d)

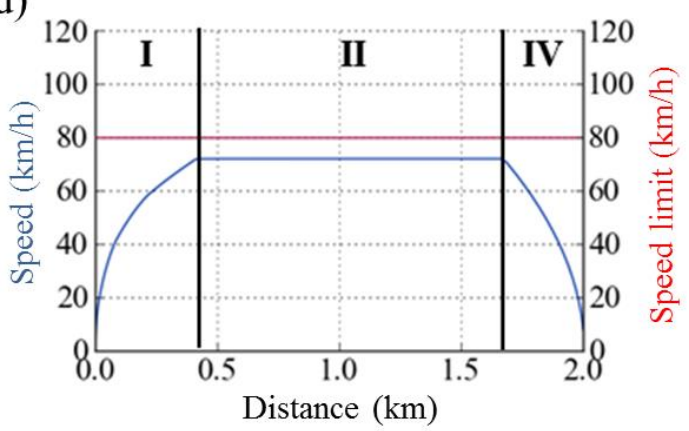

322 Figure 3. (a) Acceleration (I), saw tooth speed holding (II), coasting (III), braking phase

323 (IV) - (b) Acceleration (I), constant speed holding (II), coasting (III), braking phase (IV)

324 - (c) Acceleration (I), saw tooth speed holding (II), braking phase (IV) - (d)

325 Acceleration (I), constant speed holding (II), braking phase (IV).

\subsubsection{Modelling approach for power transmission subsystems}

Two types of hydromechanic transmissions are regarded in this work:

(1) A 4-speed automatic transmission [40] based on a power split principle between a hydrodynamic converter and planetary gear sets. In the first gear the input power is divided steplessly between a hydrodynamic converter and the mechanical part of the transmission. In gears two to four the traction power is transmitted mechanically.

(2) A six-speed automatic transmission [41] using a combination of starting converter for low speeds with three planetary gear sets to allow for six gear ratios at higher speeds. 
337 summation gearbox with an electric motor at the secondary side of the hydromechanic

338 gearbox as shown in the bottom half of Figure 4. For the parameterization of the

339 electric motor, the same values as for the commercially available traction motor HDS

340300 by BAE Systems are used. The peak power output is $230 \mathrm{~kW}$ and the maximum

341 continuous torque $2,915 \mathrm{Nm}$. The operating range is from 0 to $2,640 \mathrm{rpm}$ [42].

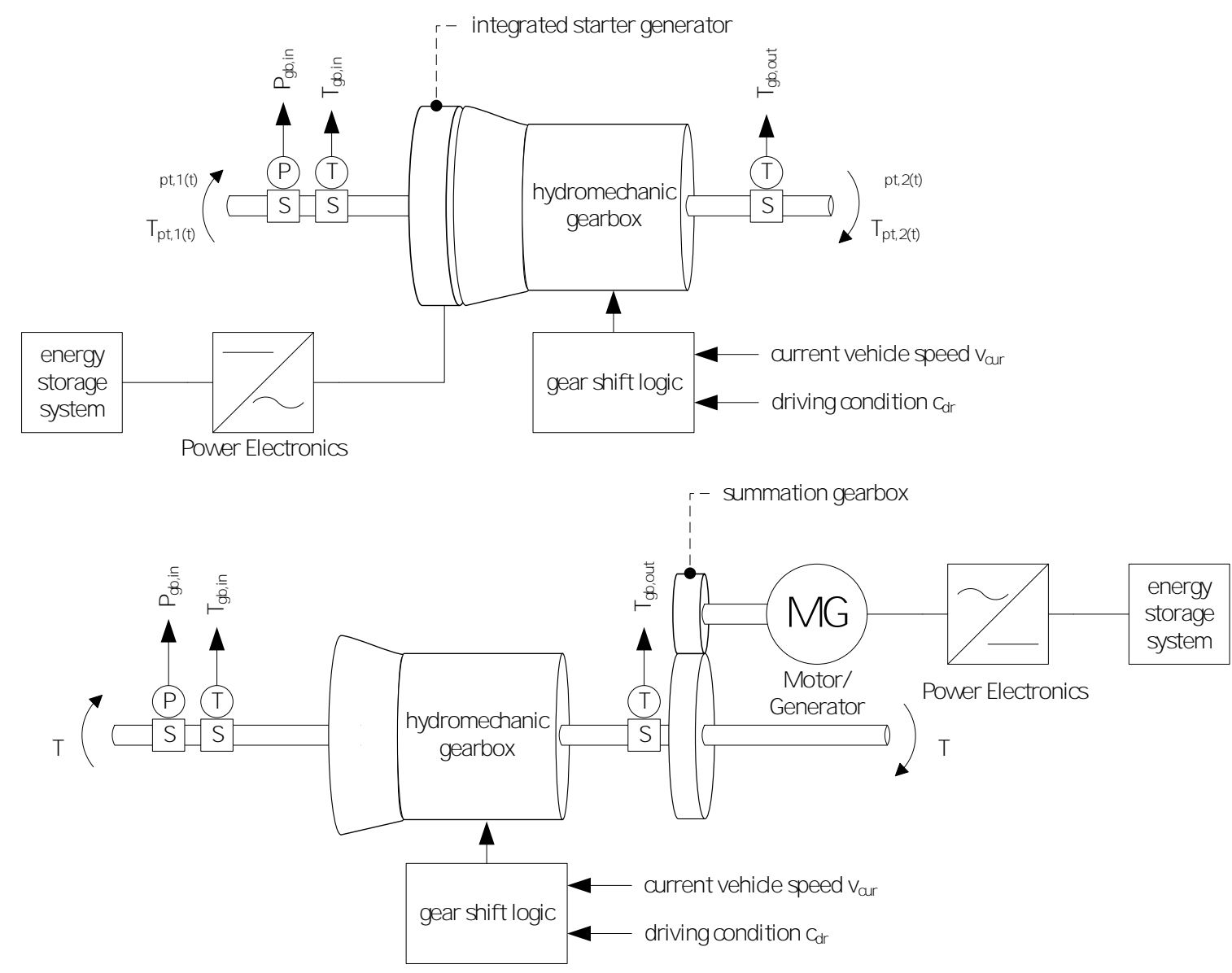

344 Figure 4. General Outline of hybridized hydromechanic gearboxes.

The hybrid version of the six-gear transmission uses an integrated starter

347 generator (ISG) at the primary side to allow for electric boosting and energy

348 recuperation during braking phases. The top half of Figure 4 shows the general outline.

349 The ISG is parameterized according to a product offered by BAE Systems with the 
HDS 300 traction generator. It has a maximum power output of $230 \mathrm{~kW}$, an operating

351

353

354

364

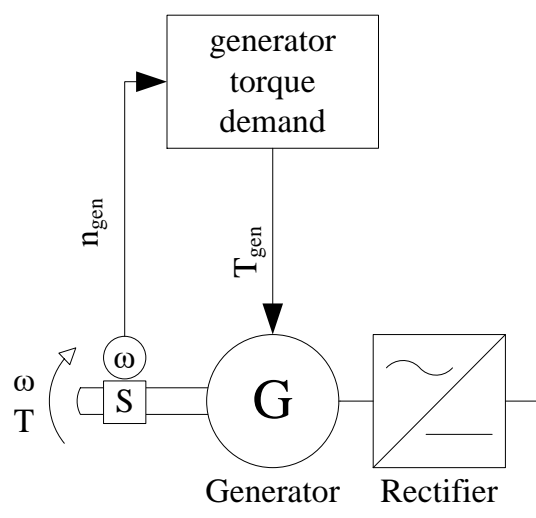

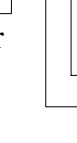
the DC link. speed range of $0-2,000 \mathrm{rpm}$ and a maximum continuous torque of $1,100 \mathrm{Nm}$ [42]. A diesel-electric propulsion system consists of a diesel engine which is connected to a generator. This generator feeds energy to a DC link via a rectifier. To drive the vehicle, one or several controllable electric motors are connected to the DC link. The general outline of the simulation model of electric power transmission is shown in Figure 5. For simplification purposes, only one electric motor is used in the simulation and the overall power and torque is set accordingly. One main advantage of electric transmissions in terms of hybridization is the reduced complexity of ESS integration since a DC link is already available and hence only a DC/DC controller is necessary to connect the ESS with the propulsion system (cf. Figure 5). A further benefit is the possibility to replace the generator with an alternative power generation source, e.g. a fuel cell as shown by Washing and Pulugurtha in [4].

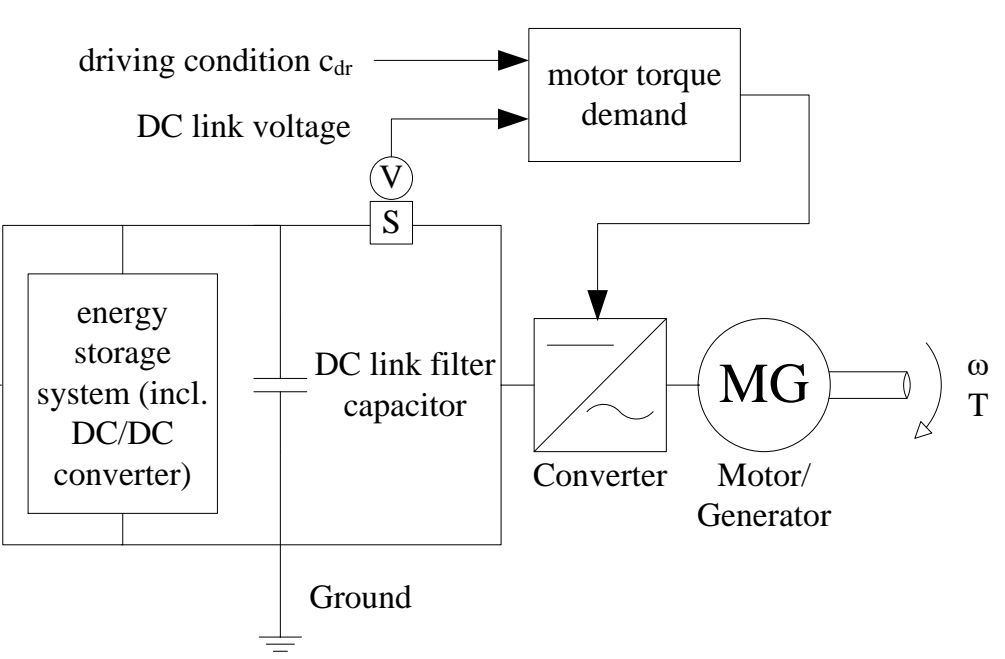

Figure 5. General outline of an electric power transmission with an ESS integrated in

\subsubsection{Modelling approach for electrical energy storage subsystems}

Three different energy storage technologies as described in the preceding sections are modelled with the help of the multi-domain LMS Imagine.Lab Amesim simulation 
software. The additional weight of the hybrid components is added to the weight of the

370 railway vehicle for the simulation studies.

371

The DLC component can simulate a whole module, therefore the number of cells in series and parallel have to be parameterized. Table 7 shows all the necessary

Double-layer capacitor simulation model: The DLC storage simulation model is based on the equivalent circuit shown in Figure 6. It is comprised of the nominal capacitance of one DLC cell in parallel with a leakage resistance to account for leakage losses (cf. Equation 1).
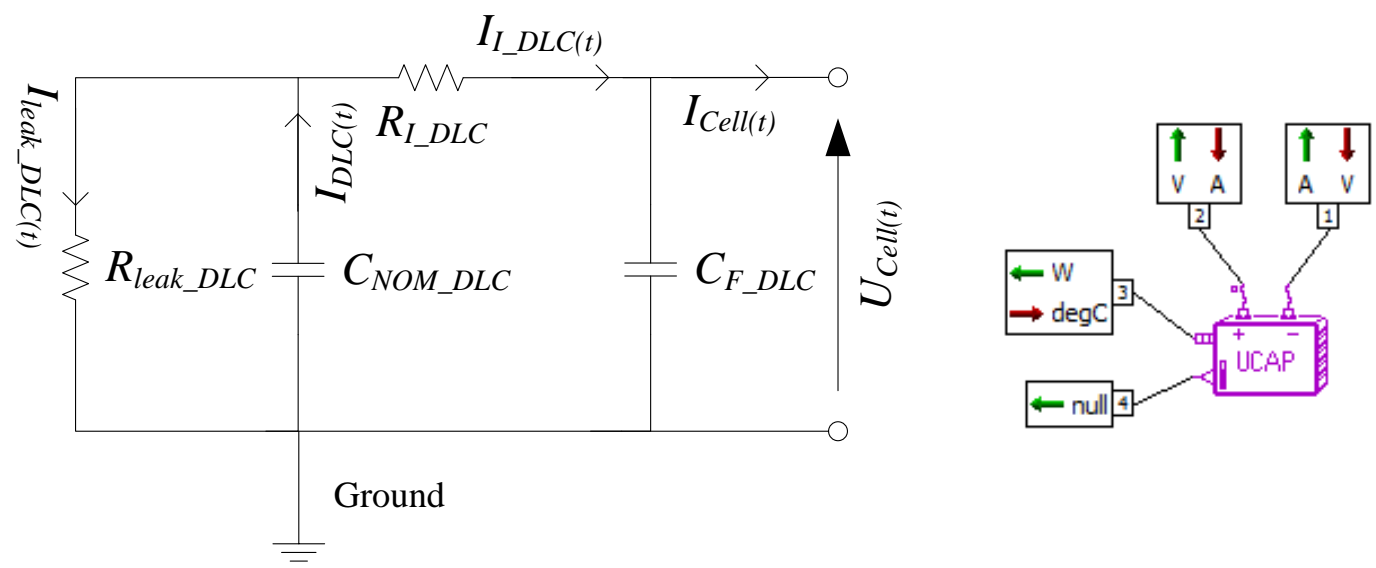

Figure 6. Equivalent circuit diagram of double-layer capacitor and Amesim simulation component.

A resistor at the input terminal represents the internal resistance of one DLC cell. A filtering capacitance is used to break algebraic loops which would otherwise occur in the simulation (cf. Equation 2).

$$
\begin{gathered}
\frac{d U_{D L C(t)}}{d t}=\frac{d U_{L e a k_{D L C}(t)}}{d t}+\frac{1}{C_{N O M_{-} D L C}}\left(I_{I_{-} D L C(t)}-I_{L e a k(t)}\right) \\
\frac{d U_{C e l l(t)}}{d t}=\frac{1}{C_{F_{-} D L C}}\left(I_{C e l l(t)}-I_{I_{-} D L C(t)}\right)
\end{gathered}
$$
global parameters for the DLC component. 
386 Table 7. Double-Layer capacitor energy storage system configurations for DMU use 387 cases.

\begin{tabular}{llll}
\hline & $\begin{array}{l}\text { Hybrid 3-coach } \\
\text { DMU with DHM 4- } \\
\text { speed transmission }\end{array}$ & $\begin{array}{l}\text { Hybrid 3-coach } \\
\text { DMU with DHM 6- } \\
\text { speed transmission }\end{array}$ & $\begin{array}{l}\text { Hybrid 3-coach } \\
\text { DMU with diesel- } \\
\text { electric propulsion } \\
\text { system }\end{array}$ \\
\hline $\begin{array}{l}\text { Number of parallel branches } \\
\text { Number of cells in series }\end{array}$ & 1 & 2 & 2 \\
Rated capacitance of one cell & $63 \mathrm{~F}$ & 5 & 6 \\
$\begin{array}{l}\text { Cell maximum continuous } \\
\text { charge/discharge current }\end{array}$ & $240 / 240 \mathrm{~A}$ & $240 / 240 \mathrm{~A}$ & $240 / 240 \mathrm{~A}$ \\
$\begin{array}{l}\text { Cell minimum/maximum } \\
\text { voltage }\end{array}$ & $12.5 / 125.0 \mathrm{~V}$ & $12.5 / 125.0 \mathrm{~V}$ & $12.5 / 125.0 \mathrm{~V}$ \\
Energy content & $0.8 \mathrm{kWh}$ & $1.4 \mathrm{kWh}$ & $1.6 \mathrm{kWh}$ \\
Efficiency of converter & $98 \%$ & $98 \%$ & $98 \%$ \\
Specific energy of ESS & $2.3 \mathrm{Wh} / \mathrm{kg}$ & $2.3 \mathrm{Wh} / \mathrm{kg}$ & $2.3 \mathrm{Wh} / \mathrm{kg}$ \\
Weight of ESS & $357 \mathrm{~kg}$ & $594 \mathrm{~kg}$ & $713 \mathrm{~kg}$ \\
\hline
\end{tabular}

389 Flywheel simulation model: In Figure 7 the analogical model and the LMS Imagine.Lab

390 Amesim simulation model for the electric flywheel energy storage system is depicted. 

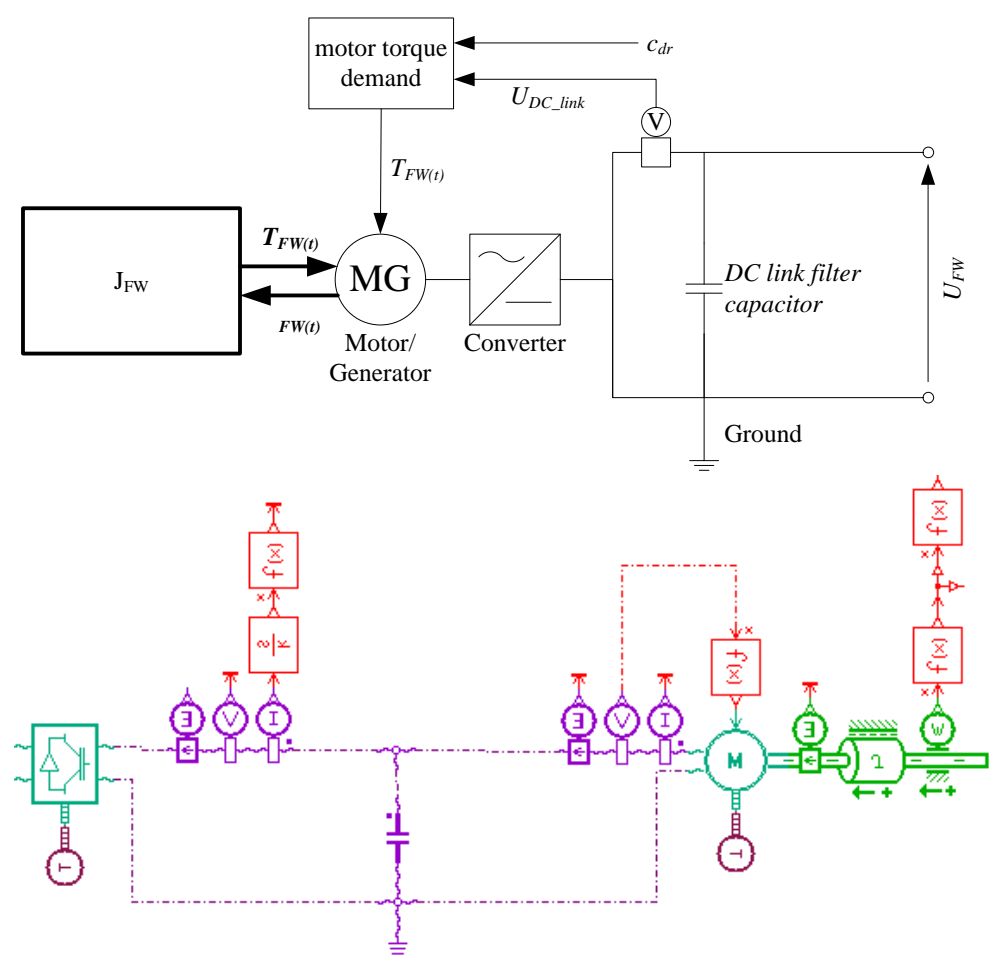

393 Figure 7. Equivalent circuit diagram of flywheel energy storage system and Amesim

394 simulation component.

The rotor of the flywheel is modelled as a rotary mass with an inertia $I$

397 calculated by the user given parameters $E M a x \_F w$ describing the energy content of the

398 flywheel and the maximum rotary speed of the flywheel $n M a x \_E M o t o r \_F w$ and

399 minimum rotary speed $n M i n \_E M o t o r \_F w$ with the following equation 3. A similar

400 approach is used by Wu et al. in [3].

401

$$
I=2 \cdot 3600 \cdot \frac{E M a x \_F w}{\left(n M a x_{-} E M o t o r_{-} F w \cdot \frac{\pi}{30}\right)^{2}-\left(n M i n \_E M o t o r_{-} F w \cdot \frac{\pi}{30}\right)^{2}}
$$

403 decelerate the rotor. The electric motor/generator is connected to a DC link and its

404 torque output is controlled by keeping the voltage of the DC link constant. A model of a converter is added to the DC link to account for converter losses which would occur in a 
406 real flywheel energy storage system. Table 8 shows all the parameters necessary to

407 parameterize the flywheel ESS.

408 Table 8. Flywheel energy storage system configurations for DMU use cases.

\begin{tabular}{llll}
\hline & $\begin{array}{l}\text { Hybrid 3-coach } \\
\text { DMU with DHM 4- } \\
\text { speed transmission }\end{array}$ & $\begin{array}{l}\text { Hybrid 3-coach } \\
\text { DMU with DHM 6- } \\
\text { speed transmission }\end{array}$ & $\begin{array}{l}\text { Hybrid 3-coach } \\
\text { DMU with diesel- } \\
\text { electric propulsion } \\
\text { system }\end{array}$ \\
\hline $\begin{array}{l}\text { Number of parallel flywheels } \\
\text { Maximum power output of } \\
\text { flywheel E-Motor / Generator }\end{array}$ & $\begin{array}{l}300 \mathrm{~kW} \\
(50 \mathrm{sec} \text { max })\end{array}$ & $\begin{array}{l}300 \mathrm{~kW} \\
(50 \mathrm{sec} \text { max })\end{array}$ & $\begin{array}{l}300 \mathrm{~kW} \\
(50 \mathrm{sec} \text { max })\end{array}$ \\
$\begin{array}{l}\text { Efficiency of flywheel } \\
\text { E-Motor }\end{array}$ & $95 \%$ & $95 \%$ & $95 \%$ \\
Maximum speed of flywheel & $22,000 \mathrm{rpm}$ & $22,000 \mathrm{rpm}$ & $22,000 \mathrm{rpm}$ \\
Energy content of Flywheel & $4 \mathrm{kWh}$ & $4 \mathrm{kWh}$ & $4 \mathrm{kWh}$ \\
Specific energy of ESS & $10.6 \mathrm{Wh} / \mathrm{kg}$ & $10.6 \mathrm{Wh} / \mathrm{kg}$ & $10.6 \mathrm{Wh} / \mathrm{kg}$ \\
Efficiency of converter & $98 \%$ & $98 \%$ & $98 \%$ \\
Weight of ESS & 375 & 375 & 750 \\
\hline
\end{tabular}

409

410 Lithium-Ion battery simulation model: LMS Imagine.Lab Amesim offers a special

411 library for the simulation of electrical energy storage systems. One submodel of the

412 library is designed for the simulation of a lithium-ion battery. It is based on the

413 equivalent electrical circuit of a battery as shown in Figure 8, which consist of a

414 constant voltage source connected to a resistor (cf. equation 4). The voltage source is

415 equal to the open circuit voltage of the battery and the resistor accounts for the internal

416 losses during current flow. The battery model allows simulating a complete battery

417 pack, therefore the number of cells in series and in parallel have to be given by the user. 


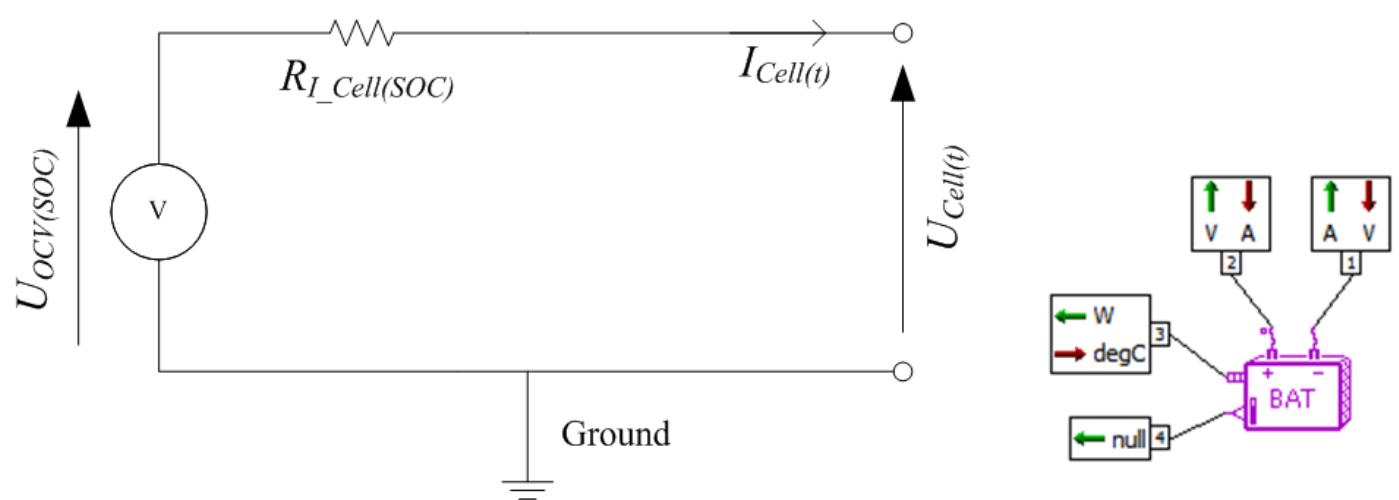

419 Figure 8. Equivalent circuit diagram of Li-Ion battery and Amesim battery simulation 420 component.

$$
\mathbf{U}_{\text {Cell }(t)}=\mathbf{U}_{\text {OCV(SOC) }}-\mathbf{I}_{\text {Cell }(t)} \cdot \mathbf{R}_{\mathbf{I}_{-} \operatorname{Cell}(\mathbf{S O C})}
$$

423 signals for the lost power and the battery SOC. The information about the current SOC

424 in addition with the sensor signals for the voltage and the current at the output of the

425 battery, are used to control the battery with the help of a battery safety control unit 426 model as shown in Figure 9.

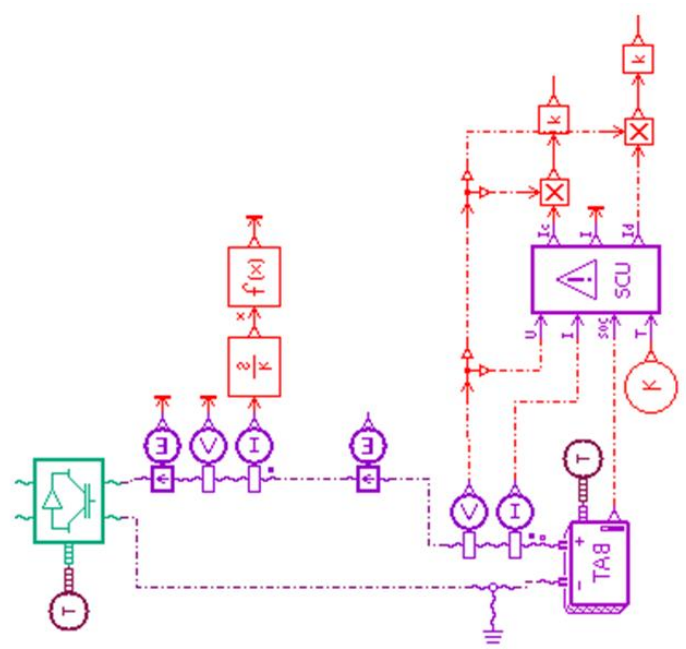

428 Figure 9. Model of the Li-Ion battery with safety control unit and converter. 
431 battery doesn't exceed specified current and voltage limits depending on time and

432 battery temperature. The dependence on battery temperature will not be regarded in this

433 work because detailed information about temperature dependent battery characteristics

434 is hardly available. Table 9 shows all the parameters necessary for the battery model

435 parameterization.

436 Table 9. Li-Ion energy storage system configurations for DMU use cases.

\begin{tabular}{|c|c|c|c|}
\hline & $\begin{array}{l}\text { Hybrid 3-coach } \\
\text { DMU with DHM 4- } \\
\text { speed transmission }\end{array}$ & $\begin{array}{l}\text { Hybrid 3-coach } \\
\text { DMU with DHM 6- } \\
\text { speed transmission }\end{array}$ & $\begin{array}{l}\text { Hybrid 3-coach } \\
\text { DMU with diesel- } \\
\text { electric propulsion } \\
\text { system }\end{array}$ \\
\hline Number of parallel branches & 2 & 3 & 4 \\
\hline Number of cells in series & 285 & 326 & 306 \\
\hline Capacity of one cell & $20 \mathrm{Ah}$ & $20 \mathrm{Ah}$ & $20 \mathrm{Ah}$ \\
\hline $\begin{array}{l}\text { Cell maximum continuous } \\
\text { charge/discharge current }\end{array}$ & $160 / 160 \mathrm{~A}$ & $160 / 160 \mathrm{~A}$ & $160 / 160 \mathrm{~A}$ \\
\hline $\begin{array}{l}\text { Cell maximum pulse } \\
\text { charge/discharge current } \\
(\max .30 \mathrm{sec})\end{array}$ & $355 / 355 \mathrm{~A}$ & $355 / 355 \mathrm{~A}$ & $355 / 355 \mathrm{~A}$ \\
\hline Cell nominal voltage & $2.3 \mathrm{~V}$ & $2.3 \mathrm{~V}$ & $2.3 \mathrm{~V}$ \\
\hline $\begin{array}{l}\text { Cell minimum/maximum } \\
\text { voltage }\end{array}$ & $1.8 / 2.8 \mathrm{~V}$ & $1.8 / 2.8 \mathrm{~V}$ & $1.8 / 2.8 \mathrm{~V}$ \\
\hline Energy content & $26.2 \mathrm{kWh}$ & $45.0 \mathrm{kWh}$ & $56.3 \mathrm{kWh}$ \\
\hline Efficiency of converter & $98 \%$ & $98 \%$ & $98 \%$ \\
\hline Specific energy of ESS & $75 \mathrm{Wh} / \mathrm{kg}$ & $75 \mathrm{Wh} / \mathrm{kg}$ & $75 \mathrm{Wh} / \mathrm{kg}$ \\
\hline Weight of ESS & $350 \mathrm{~kg}$ & $600 \mathrm{~kg}$ & $751 \mathrm{~kg}$ \\
\hline
\end{tabular}

437

\subsection{Discussion of simulation results}

\subsubsection{Suburban service profile}

440 Table 10 shows the simulated fuel consumptions for the generic 3-car DMU on the

$44140 \mathrm{~km}$ long suburban service profile [43] with $10 \%$ added contingency time between 
442 stations for unscheduled service disruptions or signal stops. A combination of diesel-

443 electric transmission and battery ESS achieves the lowest fuel consumption of

444103.6 litres of diesel fuel for the given route, which equals a saving of $21.6 \%$. The

445 results shown in Table 10 represent the driving style with the lowest fuel consumption

446 for each simulated combination of power transmission and ESS. It can be seen that in

447 case of a 4-speed transmission based on a power-split principle driving strategy a) has

448 to be favoured for the hybrid configurations. The same applies for the diesel-electric

449 powertrain. The regarded six-speed automatic transmission with a flywheel ESS or

450 battery ESS achieves the lowest fuel consumptions with driving strategy b), where no

451 sawtooth driving style is applied. Only the DLC ESS requires driving strategy a) to

452 minimize the fuel consumption.

453 Table 10. Simulated fuel consumptions and utilized driving strategy in brackets for the 454 generic 3-car DMU on suburban service profile with $10 \%$ added contingency time.

\begin{tabular}{|c|c|c|c|}
\hline Vehicle & Generic3-car DMU & & \\
\hline Power transmission & $\begin{array}{l}\text { Diesel- } \\
\text { hydromechanic } \\
\text { (4-speed automatic } \\
\text { transmission) }\end{array}$ & $\begin{array}{l}\text { Diesel- } \\
\text { hydromechanic } \\
\text { (6-speed automatic } \\
\text { transmission) }\end{array}$ & Diesel-electric \\
\hline Standard vehicle & $145.8 \operatorname{ltr}(\mathrm{c})$ & $126.5 \operatorname{ltr}(\mathrm{b})$ & $132.2 \operatorname{ltr}(b)$ \\
\hline $\begin{array}{l}\text { Hybrid with DLC } \\
\text { ESS }\end{array}$ & $123.3 \operatorname{ltr}(\mathrm{a})$ & $114.3 \operatorname{ltr}(\mathrm{a})$ & $122.2 \operatorname{ltr}(\mathrm{a})$ \\
\hline $\begin{array}{l}\text { Hybrid with } \\
\text { flywheel ESS }\end{array}$ & $110.7 \operatorname{ltr}(\mathrm{a})$ & $111.2 \operatorname{ltr}(b)$ & 111.81tr (a) \\
\hline $\begin{array}{l}\text { Hybrid with battery } \\
\text { ESS }\end{array}$ & $113.2 \operatorname{ltr}(\mathrm{a})$ & $110.6 \operatorname{ltr}(\mathrm{b})$ & $103.6 \operatorname{ltr}(\mathrm{a})$ \\
\hline
\end{tabular}

In Figure 10 Sankey diagrams for the two hybrid configurations with the highest

458 fuel savings, namely diesel-hydromechanic (6-speed) with battery ESS and diesel-

459 electric with battery ESS, are depicted. The two electric motors of the diesel-electric

460 powertrain with a combined power output of $500 \mathrm{~kW}$ per railpack allow for more brake 
462 power of $230 \mathrm{~kW}$. This leads to a lower fuel consumption on the route despite the fact

463 that the automatic transmission has a higher efficiency since no energy needs to be

464 converted via a DC link. The tank-to-wheel efficiency of the diesel-hydromechanic (6-

465 speed) powertrain is $29.0 \%$ for the standard powertrain and $33.1 \%$ for the hybrid

466 powertrain with battery ESS. Regarding the diesel-electric DMU-3, the tank-to-wheel

467 efficiency is increased from $22.2 \%$ to $28.3 \%$.

\section{DMU-3 / suburban / diesel-hydromechanic (6-speed) / battery ESS / strategy b)}

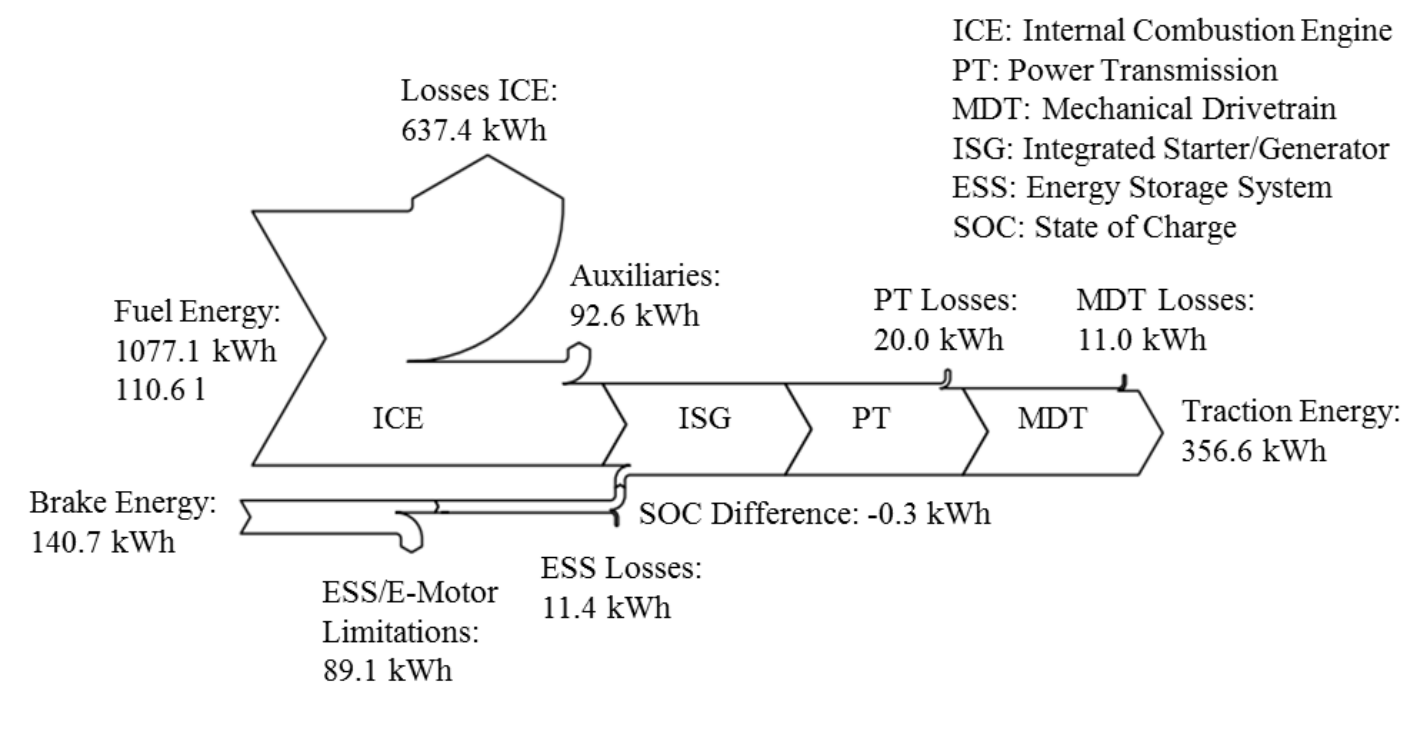

DMU-3 / suburban / diesel-electric / battery ESS / strategy a)

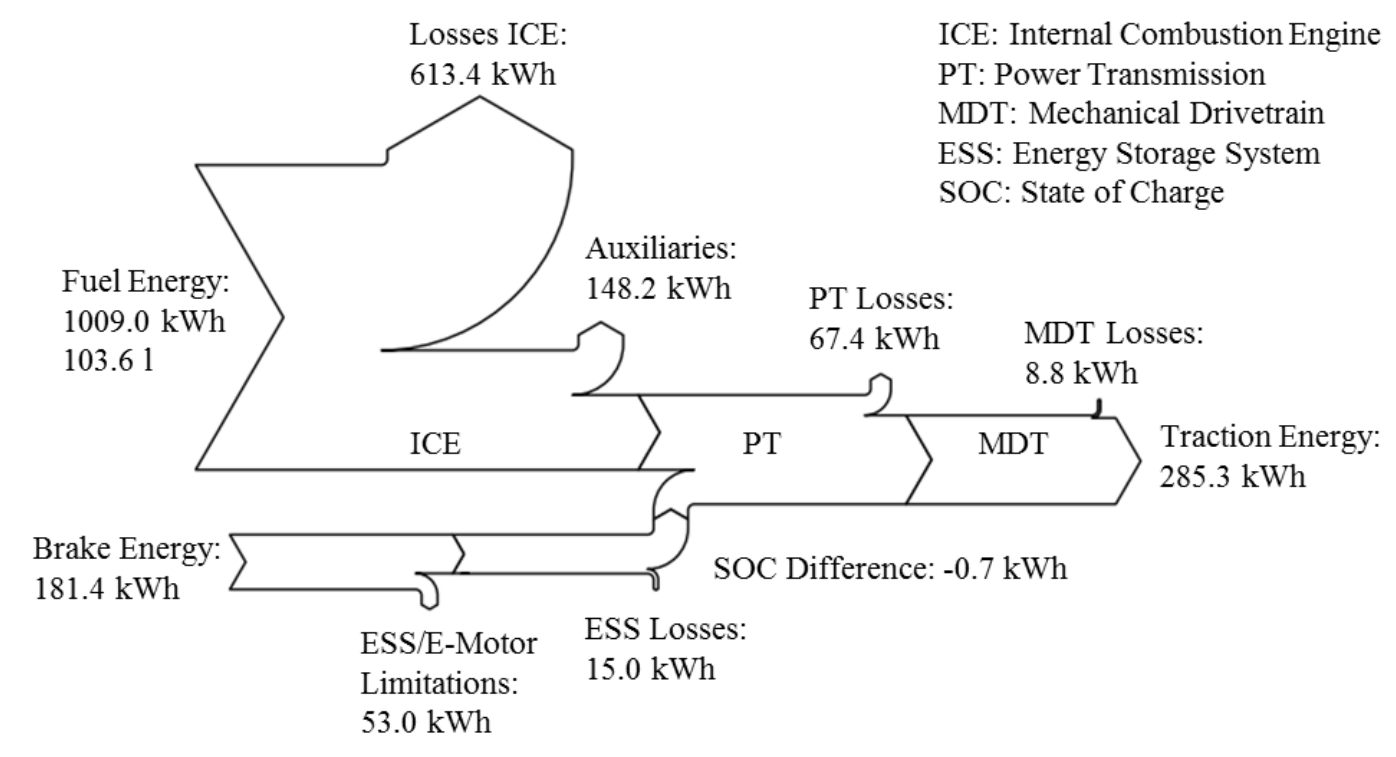

Figure 10. Sankey diagrams representing the simulated energy flow for the two hybrid propulsion systems with the lowest fuel consumption on the suburban service profile. 
473 On the regional service profile [43] with a length of $70 \mathrm{~km}$ and 15 station stops, the

474 following simulations results are achieved (see Table 11). The lowest overall fuel

475 consumption of 170.9 litres of diesel fuel is achieved with a combination of diesel-

476 electric powertrain with a battery ESS. The fuel saving for this hybrid configuration is

$477 \quad 18.5 \%$. In general, the fuel savings are slightly lower due to the longer average station

478 distance of $5.0 \mathrm{~km}$ compared to $3.6 \mathrm{~km}$ for the suburban service profile.

479 Table 11. Simulated fuel consumptions and utilized driving strategy in brackets for the 480 generic 3-car DMU on regional service profile with $10 \%$ added contingency time.

\begin{tabular}{|c|c|c|c|}
\hline \multirow{2}{*}{$\begin{array}{l}\text { Vehicle } \\
\text { Power transmission }\end{array}$} & \multicolumn{3}{|l|}{ Generic3-car DMU } \\
\hline & $\begin{array}{l}\text { Diesel- } \\
\text { hydromechanic } \\
\text { (4-speed automatic } \\
\text { transmission) }\end{array}$ & $\begin{array}{l}\text { Diesel- } \\
\text { hydromechanic } \\
\text { (6-speed automatic } \\
\text { transmission) }\end{array}$ & Diesel-electric \\
\hline Standard vehicle & $218.5 \operatorname{ltr}(\mathrm{a})$ & $198.7 \operatorname{ltr}(b)$ & $209.7 \operatorname{ltr}(\mathrm{a})$ \\
\hline $\begin{array}{l}\text { Hybrid with DLC } \\
\text { ESS }\end{array}$ & 193.11tr (a) & $182.6 \operatorname{ltr}(\mathrm{b})$ & $195.3 \operatorname{ltr}(b)$ \\
\hline $\begin{array}{l}\text { Hybrid with } \\
\text { flywheel ESS }\end{array}$ & $177.3 \operatorname{ltr}(\mathrm{a})$ & $178.6 \operatorname{ltr}(b)$ & $184.4 \operatorname{ltr}(\mathrm{b})$ \\
\hline $\begin{array}{l}\text { Hybrid with battery } \\
\text { ESS }\end{array}$ & $180.7 \operatorname{ltr}(a)$ & $177.1 \operatorname{ltr}(b)$ & $170.9 \operatorname{ltr}(\mathrm{a})$ \\
\hline
\end{tabular}

481

482

Figure 11 shows Sankey diagrams for the two hybrid DMU-3 configurations

483 diesel-hydromechanic (6-speed) with battery ESS and diesel-electric with battery ESS

484 as depicted in the preceding section for the suburban service profile. The diesel-electric

485 vehicle with battery ESS achieves better acceleration characteristics and therefore needs

486 less traction energy, since it can make better use of coasting phases. Similar to the

487 suburban service profile the benefit of the more powerful electric motor in the diesel-

488 electric powertrain to allow for more brake energy recovery leads to a lower overall fuel

489 consumption. For the simulated diesel-hydromechanic (6-speed) powertrain the tank-to- 
490 wheel efficiency is improved from $29.8 \%$ to $33.3 \%$ by hybridization with the regarded

491 battery ESS. For the diesel-electric powertrain an increase from $22.7 \%$ to $27.7 \%$ is

492 achieved.

DMU-3 / regional / diesel-hydromechanic (6-speed) / battery ESS / strategy b)

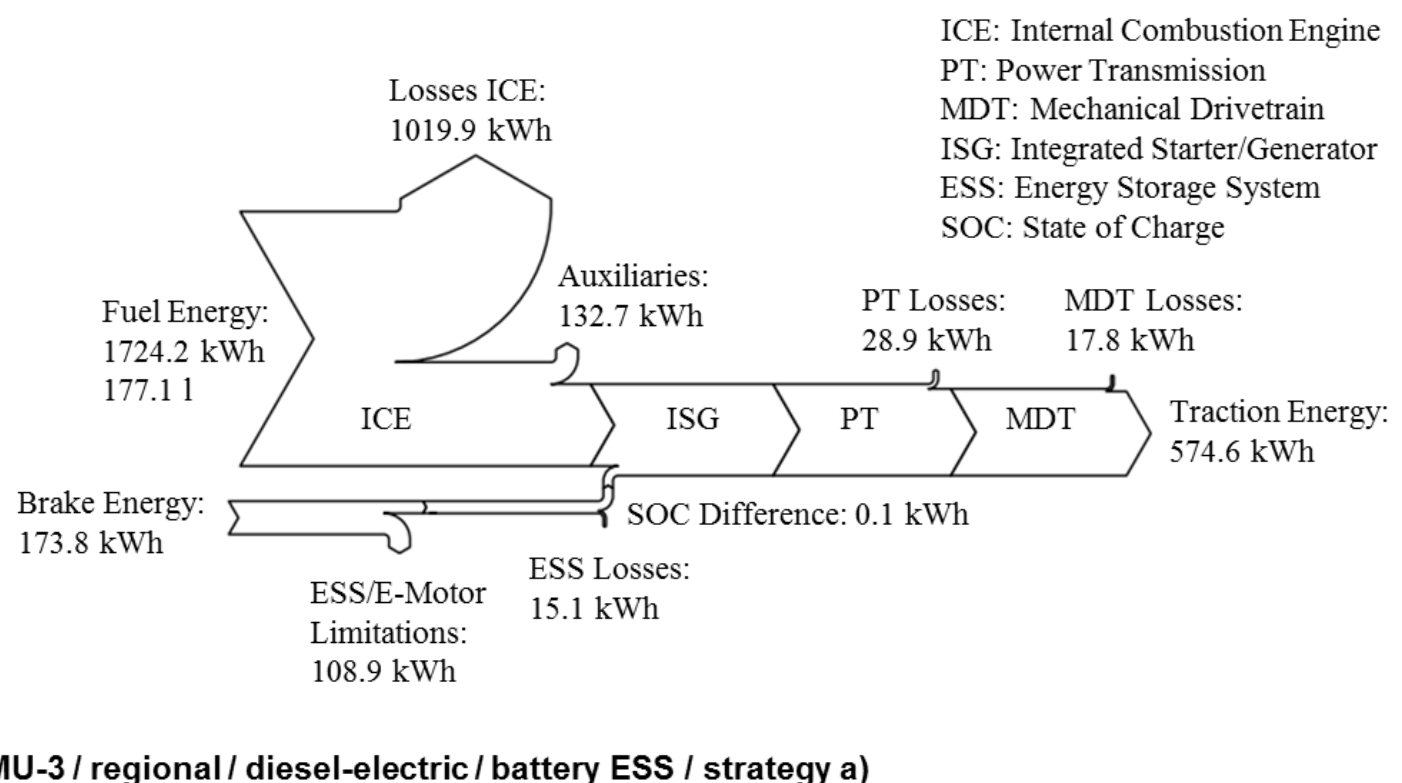

DMU-3 / regional / diesel-electric / battery ESS / strategy a)

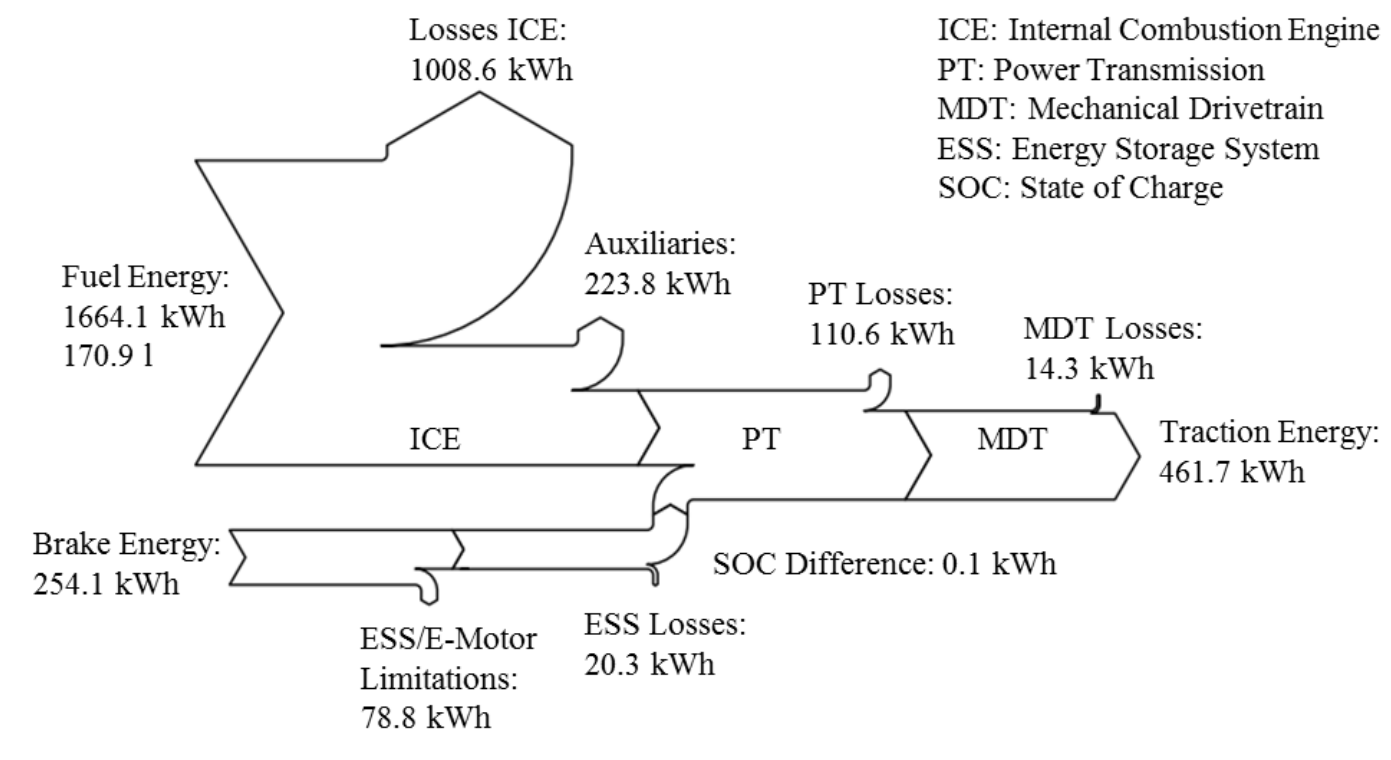

495 Figure 11. Sankey diagrams representing the simulated energy flow for the DMU-3 with

496 the two hybrid propulsion systems diesel-hydromechanic with battery ESS and diesel-

497 electric with battery ESS on the regional service profile.

\section{Conclusion}

499 The aim of the study discussed in this paper is to analyse the potential for hybridization 
of a generic DMU in a three-car formation based on multi-domain simulation models.

501 Three different types of propulsions systems are regarded: a 4-speed hydromechanic transmission, a 6-speed hydromechanic transmission and an electric transmission. In order to store brake energy and support the diesel engine during acceleration phases,

504 three type of electrical ESS are considered in the study (double layer capacitor, flywheel 505 and lithium-ion battery).

506 The simulation results show that the standard DMU-3 with a six-speed

507 hydromechanic transmission achieves the best fuel economy on the suburban and

508 regional service profile based on the given use case. For the regarded hybridized

509 powertrain configurations, on both routes a diesel-electric powertrain with a battery

510 ESS has the lowest fuel consumption. Sankey diagram analyses show that this type of

511 powertrain allows for a high rate of brake energy recovery. In addition to fuel savings,

512 hybridizing a diesel-electric powertrain to a series hybrid has further benefits in terms of

513 reduced integration efforts compared to hydromechanic parallel hybrid powertrains. The

514 availability of a DC-link and an electric traction motor allows for reduced costs of

515 hybrid components, which is an important area for further research.

516 In order to increase the future significance of the developed simulation models,

517 follow-on work of the authors will investigate on improved energy management

518 functions as well as driving strategies to achieve higher improvements in fuel

519 consumption for hybrid DMUs. One important aspect to be regarded is the

520 electrification of auxiliary systems to allow for engine shut off in station stops as well as

521 locally emission free driving with all of the traction energy supplied by the ESS. In

522 addition, powerful future battery technologies could allow for diesel engine downsizing

523 and in the long run for a complete replacement of the diesel engine, which would result

524 in an electric multiple unit (EMU) with a traction battery used for propulsion. 
that the widespread advent of hybrid DMUs is only a matter of time in order to secure

the future competitiveness of diesel engines for passenger transportation.

\section{References}

[1] International Union of Railways (UIC) and the International Energy Agency (IEA). Railway handbook 2014: Energy consumption and $\mathrm{CO}_{2}$ emissions. 2014. Available from: http://old.uic.org/spip.php?article3193

[2] Spiryagin M, Wolfs P, Szanto F, Sun Y Q, Cole C, Nielsen D. Application of flywheel energy storage for heavy haul locomotives. Journal of Applied Energy. 2015. DOI:10.1016/j.apenergy.2015.02.082

[3] Spiryagin M, Wu Q, Wolfs P, Sun Y, Cole C. Comparison of locomotive energy storage systems for heavy-haul operation. International Journal of Rail Transportation. 2017. DOI:10.1080/23248378.2017.1325719

[4] Washing EM, Pulugurtha SS. Energy demand and emission production comparison of electric, hydrogen and hydrogen-hybrid light rail trains. International Journal of Rail Transportation. 2015. DOI:10.1080/23248378.2015.1086554

[5] Vazquez S, Lukic S M, Galvan E, Franquelo L G, Carrasco J M. Energy storage systems for transport and grid applications. IEEE Transactions on Industrial Electronics. 2010;57; 3881-3895. DOI:10.1109/TIE.2010.2076414

[6] Gonzalez-Gil A, Palacin R, Batty P. Sustainable urban rail systems: Strategies and technologies for optimal management of regenerative braking energy. Energy Conversion and Management. 2013. DOI:10.1016/j.enconman.2013.06.039.

[7] Gonzalez-Gil A, Palacin R, Batty P, Powell J P. A systems approach to reduce urban rail energy consumption. Energy Conversion and Management. 2014. DOI: 10.1016/j.enconman.2014.01.060.

[8] Meinert M, Melzer M, Kamburow C, Palacin R, Leska M, Aschemann H. Benefits of hybridisation of diesel driven railway vehicles: Energy management strategies and life-cycle costs appraisal. Journal of Applied Energy. 2015;157;897-904. DOI:10.1016/j.apenergy.2015.05.051

[9] Meinert M, Prenleloup P, Schmid S, Palacin R. Energy storage technologies and hybrid architectures for specific diesel driven rail duty cycles: Design and system integration aspects. Journal of Applied Energy. 2015;157;619-629. DOI:10.1016/j.apenergy.2015.05.015

[10] Ogasa M. Application of energy storage technologies for electric railway vehicles - examples with hybrid electric railway vehicles. IEEJ Transactions on 
Electrical and Electronic Engineering. 2010;5(3);304-301. DOI:10.1002/tee.20534

[11] Meinert M. New mobile energy storage system for rolling stock. European Conference on Power Electronics and Applications. 2009. ISBN:978-1-42444432-8

[12] Iannuzzi D. Improvement of the energy recovery of traction electrical drives using supercapacitors. Power Electronics and Motion Control Conference. 2008. DOI:10.1109/EPEPEMC.2008.4635475

[13] Steiner M, Klohr M, Pagiela S. Energy storage system with ultracaps on board of railway vehicles. European Conference on Power Electronics and Applications. 2007. DOI:10.1109/EPE.2007.4417400

[14] Lehmann I, Schmalzing C, Werner C, Bold U. Hybrid-Powerpack für nachhaltigen und umweltfreundlichen Triebwagenantrieb. Eisenbahntechnische Rundschau. 2011;9;18-22

[15] Railway Gazette International. Hybrid drive demonstrates $15 \%$ fuel saving. 2015. Available from: http://www.railwaygazette.com/news/traction-rollingstock/single-view/view/hybrid-drive-demonstrates-15-fuel-saving.html

[16] Fujii T, Teraya N, Osawa M. Development of a NE train. JR East Technical Review. 2004;4;62-70. Available from: www.jreast.co.jp/e/development/tech/pdf_4/Tech-no.4-62-70.pdf

[17] Shiraki N, Satou H and Arai S. A Hybrid System for Diesel Railcar Series Ki-ha E200. The 2010 International Power Electronics Conference. 2010;2853-2858. DOI:10.1109/IPEC.2010.5542319

[18] Grantham A. Hybrid high speed train unveiled. Railway Gazette International. 2007. Available from: http://www.railwaygazette.com/nc/news/singleview/view/hybrid-high-speed-train-unveiled.html

[19] Engel B, Soefker C. The innovative traction system with the flywheel of the LIREX $^{\mathrm{TM}}$. World Congress on Railway Research. 2001. Available from: http://www.uic.org/cdrom/2001/wcrr2001/pdf/sessions/1_1_3/457.pdf

[20] Research and Technology Centre of Deutsche Bahn AG. Applications for energy storage flywheels in vehicles of Deutsche Bahn AG. World Congress on Railway Research. 2001. Available from: http://www.uic.org/cdrom/2001/wcrr2001/pdf/sp/1_11/120.pdf

[21] European Commission. Public Report: Ultra Low Emission Vehicle - Transport using Advanced Propulsion 2 (ULEV-TAP II). 2005.

[22] Paukert H. Detailed specification: parameters definition (D7.2.1). Clean European Rail-Diesel. 2011. Available from: http://www.cleanerd.eu/deliverables.aspx 
600 [23] Paukert H. Definition of parameters to run emission simulation (D.7.2.2). Clean

601

602

603

604

605

606

607

608

609

610

611

612

613

614

615

616

617

618

619

620

621

622

623

624

625

626

627

628

629

630

631

632

633

634

635

636

637

638

European Rail-Diesel. 2011. Available from: http://www.cleanerd.eu/deliverables.aspx

[24] Marsilla $\mathrm{M}$ et al. Future scenarios and recommendations for implementation of hybrid solutions (D7.5.4). Clean European Rail-Diesel. 2013. Available from: http://www.cleaner-d.eu/deliverables.aspx

[25] Hillmansen S, Roberts C, McGordon A, Jennings, P. Project: Concept Validation Hybrid Trains. Final Report DfTRG/0078/2007. Birmingham Research and Development Limited. 2008.

[26] Hillmansen S, Roberts C, McGordon A, Jennings, P. DMU Hybrid Concept Evaluation. Final Report DfTRG/0078/2007. Birmingham Research and Development Limited. 2009.

[27] United Nations Economic Commission for Europe. ECE/TRANS/WP.6/2011/5 Definitions of vehicle energy types. 2011.

[28] ZF Friedrichshafen AG. Faster and Further With Purely Electric Power: First Plug-in Hybrid Transmission by ZF Enters Volume Production. Available from: http://www.zf.com

[29] Maxwell Technologies Inc. 125 V Heavy Transportation Module BMOD0063 P125 B08 63F/125V Datasheet. 2013. Available from: http://www.maxwell.com/

[30] Siemens AG. Sitras MES: Mobile energy storage unit for railway vehicles. Available from: http://w3.usa.siemens.com/mobility/us/Documents/en/railsolutions/railway-electrification/dc-traction-power-supply/sitras-mes-en.pdf

[31] Green Car Congress. New Urbino hybrid bus with Voith parallel hybrid system. 2011. Available from: http://www.greencarcongress.com/2011/03/urbino20110325.html

[32] GKN Hybrid Power. Gyrodrive Flywheel Energy Storage System. GKN Land Systems. 2015. Available from: http://www.gkn.com/landsystems/brands/hybridpower/media/downloads/Pages/brochures.aspx

[33] Hansen J, O'Kain D. An Assessment of Flywheel High Power Energy Storage Technology for Hybrid Vehicles Oak Ridge National Laboratory Report ORNL/ TM-2010/280. 2011.

[34] Thoolen F. Flywheels as High Power Storage Devices for Mobile Applications. International Renewable Energy Storage Conference. 2006.

[35] Toshiba. SCiB ${ }^{\text {TM }}$ Cell Data. 2015. Available from: http://www.scib.jp/en/product/detail.htm

[36] Takami N, Inagaki H, Tatebayashi Y, Saruwatari H, Honda K, Egusa S. Highpower and long-life lithium-ion batteries using lithium titanium oxide anode for 
automotive and stationary power applications. Journal of Power Sources. DOI:10.1016/j.jpowsour.2012.11.055

[37] Dittus H, Huelsebusch D, Ungethuem J. Reducing DMU fuel consumption by means of hybrid energy storage. European Transport Research Review. 2011. DOI:10.1007/s12544-011-0053-6

[38] Powell JP, Palacin R. A comparison of modelled and real-life driving profiles for the simulation of railway vehicle operation. Transportation Planning and Technology. 2015;38(1);78-93. DOI:10.1080/03081060.2014.976984

[39] Milroy I P, Forsythe W. Timekeeping control of an automatically driven train. Transportation Research Part B: Methodological, 1984;18(6);459-468. DOI: 10.1016/0191-2615(85)90012-8

[40] Voith Turbo. Combining Ride Comfort with Economy. DIWA.5. 2012 http://www.voith.com

[41] Naunheimer H, Bertsche B, Ryborz J, Novak W. Automotive Transmissions: Fundamentals, Selection, Design and Application. 2011. ISBN 978-3-64216214-5

[42] BAE Systems. HybriDrive ${ }^{\circledR}$ propulsion (Hybrid-electric propulsion systems). 2017. Available from: http://www.hybridrive.com/

[43] UNIFE / UIC. Technical Recommendation: Specification and verification of energy consumption for railway rolling stock. 2010. Available from: http://www.tecrec-rail.org/100_001

[44] SAFT SA. Ion-OnBoard® Regen, the Li-ion regenerative hybrid traction battery system. Datasheet. 2017. Available from: https://www.saftbatteries.com/ 